\title{
Synthesis of a mechanically planar chiral and axially chiral
}

\section{[2] rotaxane}

Shinya Tajima, Atsuya Muranaka, Masaya Naito, Noriho Taniguch, Mei Harada, Shinobu Miyagawa, Masahiro Ueda, Hikaru Takaya, Nagao Kobayashi, Masanobu Uchiyama, and Yuji Tokunaga

Supporting Information

Table of Contents

1. Experimental $\mathrm{S}-1$

2. Figure S1. VT NMR spectra of the bis-crown ether 1.

3. Figure S2. Time-dependant NMR spectra of a mixture of $\mathbf{1}$ and $\mathbf{7 a}$. S-8

4. Figure S3. Variable-concentration NMR spectra of mixtures of $\mathbf{1}$ and 7a. S-9

5. Figure S4. Symmetry and NMR spectral signal pattern of the chiral [2]rotaxane 2.

6. Figure S5. ${ }^{1} \mathrm{H}$ NMR spectrum of the chiral [2] rotaxane $2 . \quad$ S-11

7. Figure S6. ${ }^{13} \mathrm{C}$ NMR spectra of the [2] rotaxane $2 . \quad \mathrm{S}-12$

8. Figure S7. COSY spectrum of the [2] rotaxane 2. S-14

9. Figure S8. ROESY spectrum of the [2]rotaxane 2 S-16

10. Figure S9. HSQC spectrum of the [2] rotaxane 2 S-18

11. Figure S10. HMBC spectrum of the [2] rotaxane $2 . \quad$ S-20

12. Figure S11. Mass spectrum of the [2] rotaxane 2. S-22

13. Figure S12. X-ray crystallographic structure of the [2] rotaxane $2 . \quad$ S-23

14. Table S1. X-ray crystallographic data of the [2] rotaxane $2 . \quad$ S-24

15. Figure S13. Chiral HPLC analysis of the [2]rotaxane 2. S-25

16. Figure S14. ${ }^{1} \mathrm{H}$ and ${ }^{13} \mathrm{C}$ NMR spectra of compound $4 . \quad$ S-27

17. Figure S15. ${ }^{1} \mathrm{H}$ and ${ }^{13} \mathrm{C}$ NMR spectra of the dichloride 5 S-28

18. Figure S16. ${ }^{1} \mathrm{H}$ and ${ }^{13} \mathrm{C}$ NMR spectra of the mono-crown ether $6 . \quad S-29$

19. Figure S17. ${ }^{1} \mathrm{H}$ and ${ }^{13} \mathrm{C}$ NMR spectra of the bis-crown ether $1 . \quad S-30$

20. Figure S18. ${ }^{1} \mathrm{H}$ and ${ }^{13} \mathrm{C}$ NMR spectra of the bis-ammonium salt 7c. $\quad$ S-31

21. Figure S19. ${ }^{1} \mathrm{H}$ and ${ }^{13} \mathrm{C}$ NMR spectra of the bis-ammonium salt 7a. $\quad \mathrm{S}-32$

22. Figure S20. ${ }^{1} \mathrm{H}$ and ${ }^{13} \mathrm{C}$ NMR spectra of the bis-ammonium salt 7b. $\quad S-33$

23. Figure S21. ${ }^{1} \mathrm{H}$ and ${ }^{13} \mathrm{C}$ NMR spectra of the [2] rotaxane $2 . \quad \mathrm{S}-34$ 


\section{Experimental}

\section{Materials and General Methods}

The bromocatechol $\mathbf{4}^{1}$ and the dichloride $5^{2}$ were prepared according to previously reported procedures. Toluene and DMF were dried over 4 - $\AA$ molecular sieves. Other solvents and commercially available chemicals were used as received. ${ }^{1} \mathrm{H}$ and ${ }^{13} \mathrm{C}$ NMR spectra were recorded using ECX-500II and ECA-600II spectrometers, with tetramethylsilane (TMS) as the internal standard. Mass spectra were recorded using JEOL JMS-700T (FAB) and Bruker Daltonics autoflex (MALDI) spectrometers. Infrared spectra were recorded using a JASCO FT/IR-4100 spectrometer. HPLC was performed using a Shimadzu LC-20AT apparatus, an SDD-M20A detector, and DAICEL CHIRALPAK IA3 $(0.46 \times 25 \mathrm{~cm}$ for analysis $)$ and IA $(1.0 \times 25 \mathrm{~cm}$ for separation $)$ chiral columns. CD spectra were recorded with a JASCO J-820. All reactions were performed under a positive atmosphere of dry $\mathrm{N}_{2}$. All solvents were evaporated through rotary evaporation under reduced pressure. Column chromatography was performed using Kanto Chemical silica gel $60 \mathrm{~N}$. Thin-layer chromatography was performed using Merck Kieselgel $60 \mathrm{PF}_{254}$.

\section{3-Bromo-5-tert-butylcatechol (4)}

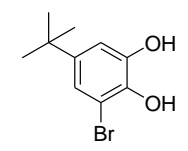

$\mathrm{N}$-Bromosuccinimide ( $4.56 \mathrm{~g}, 26.0 \mathrm{mmol})$ was added to a solution of 4-tert-butylcatechol (4.06 g, $24.0 \mathrm{mmol})$ in DMF $(20 \mathrm{~mL})$ at room temperature and then the mixture was stirred for $24 \mathrm{~h}$ at $30{ }^{\circ} \mathrm{C}$ using a water bath. The solvent was evaporated; EtOAc was added to the residue. The organic phase was washed with $\mathrm{H}_{2} \mathrm{O}$ and sat. $\mathrm{NaCl}$ (aq), then dried $\left(\mathrm{MgSO}_{4}\right)$. After evaporation of the solvent, the residue was purified through column chromatography $\left(\mathrm{SiO}_{2}\right.$; hexane/EtOAc, 10:1) to afford a colorless solid, which was recrystallized from hexane to afford colorless crystals (4.05 g, 68\%). ${ }^{1} \mathrm{H} \mathrm{NMR}(500 \mathrm{MHz}$, $\left.\mathrm{CDCl}_{3}\right): \delta 6.98(\mathrm{~d}, 1 \mathrm{H}, J=2.0 \mathrm{~Hz}), 6.90(\mathrm{~d}, 1 \mathrm{H}, J=2.0 \mathrm{~Hz}), 5.70-4.80(\mathrm{~m}, 2 \mathrm{H}), 1.25(\mathrm{~s}$, 9H). ${ }^{13} \mathrm{C} \mathrm{NMR}\left(125 \mathrm{MHz}, \mathrm{CDCl}_{3}\right): \delta 145.7,143.9,137.7,120.0,112.5,109.0,34.4,31.3$.

The ${ }^{1} \mathrm{H}$ NMR spectral data of $\mathbf{4}$ was identical to that reported previously. ${ }^{1}$

\section{Dichloride 5}

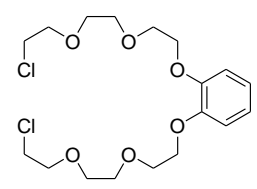

A suspension of catechol (602 mg, $5.47 \mathrm{mmol})$, [2-(2-chloroethoxy)ethoxy]ethyl tosylate (3.53 g, $10.9 \mathrm{mmol})$, and $\mathrm{K}_{2} \mathrm{CO}_{3}(2.27 \mathrm{~g}, 16.4 \mathrm{mmol})$ in $\mathrm{CH}_{3} \mathrm{CN}(40 \mathrm{~mL})$ was heated using 
an oil bath under reflux for $67 \mathrm{~h}$. After evaporation of the solvent, $10 \% \mathrm{HCl}$ (aq) was added to the residue and the aqueous phase was extracted with AcOEt. The organic extract was washed with brine, dried $\left(\mathrm{MgSO}_{4}\right)$, and concentrated. The residue was purified through column chromatography $\left(\mathrm{SiO}_{2}\right.$; toluene/AcOEt, 4:1) to afford a colorless oil (1.50 g, 67\%). ${ }^{1} \mathrm{H}$ NMR (500 MHz, $\left.\mathrm{CDCl}_{3}\right): \delta 6.95-6.88(\mathrm{~m}, 4 \mathrm{H}), 4.20-4.15(\mathrm{~m}, 4 \mathrm{H})$, $3.90-3.85$ (m, 4H), 3.79-3.73 (m, 8H), 3.72-3.68 (m, 4H), 3.66-3.61 (m, 4H). ${ }^{13} \mathrm{C}$ NMR $\left(150 \mathrm{MHz}, \mathrm{CDCl}_{3}\right): \delta 148.9,121.6,114.8,71.3,70.7,70.6,69.8,68.7,42.7$.

The ${ }^{1} \mathrm{H}$ NMR spectrum of $\mathbf{5}$ was identical to that reported previously. ${ }^{2}$

\section{Mono-crown ether 6}

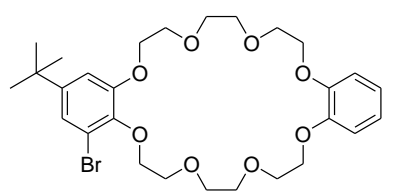

A suspension of the catechol $4(920 \mathrm{mg}, 3.70 \mathrm{mmol})$, the dichloride $5(1.54 \mathrm{~g}, 3.70 \mathrm{mmol})$, CsI (486 mg, $1.90 \mathrm{mmol})$, and $\mathrm{Cs}_{2} \mathrm{CO}_{3}(4.87 \mathrm{~g}, 15.0 \mathrm{mmol})$ in dry DMF (90 mL) was stirred for 3 days at $110^{\circ} \mathrm{C}$ using an oil bath. After evaporation of the solvent, the residue was treated with sat. ammonium chloride (aq) and extracted with EtOAc. The combined extracts were dried $\left(\mathrm{MgSO}_{4}\right)$. After evaporation of the solvent, the residue was purified through column chromatography $\left(\mathrm{SiO}_{2}\right.$; toluene/EtOAc, 3:1) to afford a colorless oil (1.50 g, 69\%). ${ }^{1} \mathrm{H}$ NMR (600 MHz, $\left.\mathrm{CDCl}_{3}\right): \delta 7.11$ (d, 1H, J = 1.7 Hz), 6.91-6.86 (m, $4 \mathrm{H}), 6.83(\mathrm{~d}, 1 \mathrm{H}, J=1.7 \mathrm{~Hz}), 4.19-4.13(\mathrm{~m}, 8 \mathrm{H}), 3.95-3.87(\mathrm{~m}, 8 \mathrm{H}), 3.87-3.76(\mathrm{~m}, 8 \mathrm{H})$, 1.27 (s, 9H). ${ }^{13} \mathrm{C}$ NMR (150 MHz, $\left.\mathrm{CDCl}_{3}\right): \delta 152.3,149.0,148.3,143.7,122.0,121.4$, 117.2, 114.31, 114.29, 110.9, 72.0, 71.15, 71.11, 71.05, 70.6, 70.4, 69.90, 69.87, 69.8, 69.5, 69.3 , 69.1, 34.6, 31.2. Two aromatic carbon signals were overlapping/missing. IR $v_{\max }(\mathrm{KBr}) \mathrm{cm}^{-1} 2957,2871,1594,1558,1506,1456,1410,1301,1256,1128,1057,746$, 658. HRMS (FAB) calcd. for $\mathrm{C}_{28} \mathrm{H}_{39} \mathrm{BrO}_{8}[\mathrm{M}+\mathrm{H}]^{+}, \mathrm{m} / z$, 582.1828; found, 582.1812 .

\section{Bis-crown ether 1}

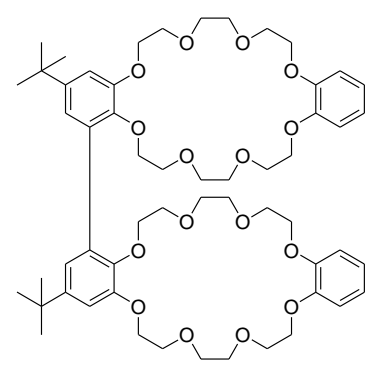

Bis(1,5-cyclooctadinene)nickel(0) (1.08 $\mathrm{g}, 3.93 \mathrm{mmol})$ was added to a solution of the mono-crown ether $6(0.92 \mathrm{~g}, 1.57 \mathrm{mmol})$ and 2,2'-bipyridine $(0.61 \mathrm{~g}, 3.93 \mathrm{mmol})$ in dry 
toluene $(16 \mathrm{~mL})$ and dry DMF $(16 \mathrm{~mL})$ and then the mixture was stirred for 2 days at $75{ }^{\circ} \mathrm{C}$ using an oil bath. After cooling, the residue was treated with dil. $\mathrm{HCl}$ (aq) and extracted with EtOAc. The combined extracts were washed with $\mathrm{H}_{2} \mathrm{O}$, then dried $\left(\mathrm{MgSO}_{4}\right)$. After evaporation of the solvent, the residue was purified through column chromatography $\left(\mathrm{SiO}_{2} ; \mathrm{CH}_{2} \mathrm{Cl}_{2} / \mathrm{MeOH}, 100: 1\right)$ to afford a viscous oil $(0.92 \mathrm{~g}, 58 \%) .{ }^{1} \mathrm{H}$ NMR (600 MHz, $\left.\mathrm{CDCl}_{3}\right): \delta 6.99(\mathrm{~d}, 2 \mathrm{H}, J=2.8 \mathrm{~Hz}), 6.90-6.85(\mathrm{~m}, 10 \mathrm{H}), 4.21-4.18(\mathrm{~m}$, $4 \mathrm{H}), 4.16-4.11(\mathrm{~m}, 8 \mathrm{H}), 3.95-3.83(\mathrm{~m}, 20 \mathrm{H}), 3.82-3.79(\mathrm{~m}, 4 \mathrm{H}), 3.76-3.73(\mathrm{~m}, 4 \mathrm{H})$, 3.63-3.60 (m, 4H), 3.55-3.52 (m, 4H), $1.29(\mathrm{~s}, 18 \mathrm{H}) .{ }^{13} \mathrm{C} \mathrm{NMR}\left(150 \mathrm{MHz}, \mathrm{CDCl}_{3}\right): \delta$ 151.4, 149.1, 149.0, 145.9, 143.7, 132.0, 121.5, 121.4, 121.1, 114.4, 114.3, 110.1, 71.6, 71.2, 71.0, 70.5, 70.4, 70.0, 69.9, 69.5, 69.4, 68.7, 34.6, 31.5. Two aliphatic carbon signals were overlapping/missing. IR $v_{\max }(\mathrm{KBr}): \mathrm{cm}^{-1} 2952,2870,1507,1456,1256,1126,1058$, 750. HRMS (FAB) calcd. for $\mathrm{C}_{56} \mathrm{H}_{79} \mathrm{O}_{16}{ }^{+}[\mathrm{M}+\mathrm{H}]^{+}, \mathrm{m} / z$ 1007.5368; found, 1007.5334. 


\section{Synthesis of the bis-ammonium salts $7 \mathrm{a}$ and $7 \mathrm{~b}$}
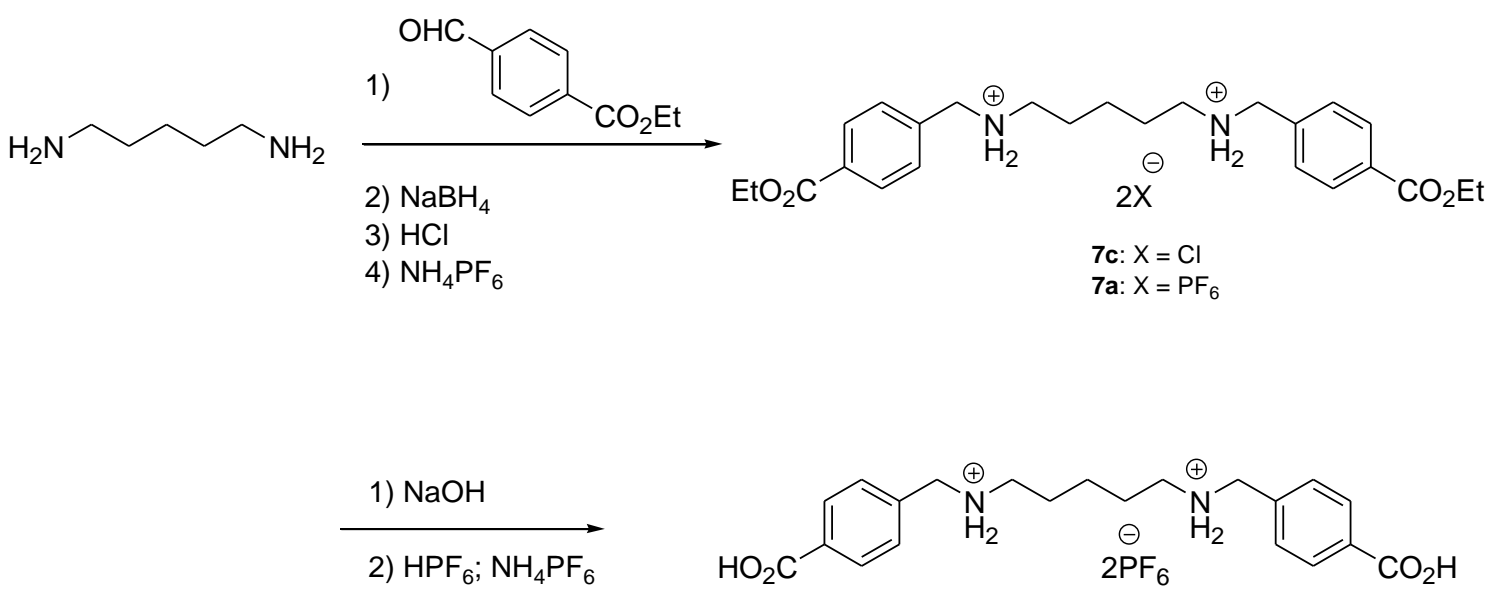

$7 b$

Scheme S1.

\section{Bis-ammonium salt 7c}

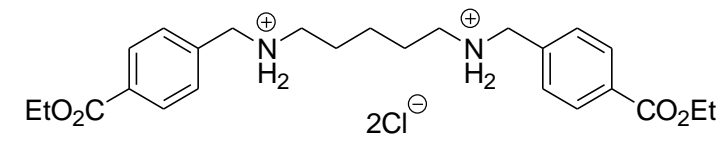

A suspension of 4-(ethoxycarbonyl)benzaldehyde (5.73 g, $33.7 \mathrm{mmol})$, 1,5diaminopentane (1.43 g, $14.0 \mathrm{mmol})$, and $\mathrm{Na}_{2} \mathrm{SO}_{4}(743.5 \mathrm{mg}, 7.01 \mathrm{mmol})$ in toluene (50 $\mathrm{mL}$ ) was heated using an oil bath at $100{ }^{\circ} \mathrm{C}$ for $20 \mathrm{~h}$. After filtration, the filtrate was concentrated. The residue was dissolved in $\mathrm{EtOH}(60 \mathrm{~mL})$ and then $\mathrm{NaBH}_{4}(3.18 \mathrm{~g}, 84.1$ mmol) was added to the solution at room temperature. After stirring at $40{ }^{\circ} \mathrm{C}$ using an oil bath for $68 \mathrm{~h}, 10 \% \mathrm{HCl}(\mathrm{aq})(30 \mathrm{~mL})$ was added to quench the excess $\mathrm{NaBH}_{4} .10 \%$ $\mathrm{Na}_{2} \mathrm{CO}_{3}(90 \mathrm{~mL})$ was added to neutralize the mixture. The aqueous phase was extracted with $\mathrm{CH}_{2} \mathrm{Cl}_{2}$. The combined extracts were washed with sat. $\mathrm{NaCl}(\mathrm{aq})$, dried $\left(\mathrm{Na}_{2} \mathrm{SO}_{4}\right)$, and concentrated. The residue was chromatographed $\left(\mathrm{SiO}_{2} ; \mathrm{CH}_{2} \mathrm{Cl}_{2} / \mathrm{MeOH}, 10: 1\right)$ to afford the corresponding diamine $(2.55 \mathrm{~g})$ as a pale-yellow oil. A solution of $\mathrm{HCl}$ in 1,4dioxane $(5.20 \mathrm{M}, 2.81 \mathrm{~mL}, 14.1 \mathrm{mmol})$ was diluted with $\mathrm{Et}_{2} \mathrm{O}(15 \mathrm{~mL})$ and then added to a solution of the product diamine $(2.00 \mathrm{~g})$ in $\mathrm{Et}_{2} \mathrm{O}(30 \mathrm{~mL})$. The mixture was stirred for 1 $\mathrm{h}$ at room temperature. The precipitate was collected by filtration and washed with $\mathrm{Et}_{2} \mathrm{O}$ to give a pale-yellow solid $(2.18 \mathrm{~g}, 39 \%)$. ${ }^{1} \mathrm{H}$ NMR (500 MHz, DMSO- $\left.d_{6}\right)$ : $\delta 9.38$ (br s, 4H), 8.01-7.95 (m, 4H), 7.74-7.68 (m, 4H), 4.34 (q, 4H, J = 7.1 Hz), 4.20 (s, 4H), 2.90 (t, $4 \mathrm{H}, J=7.5 \mathrm{~Hz}$ ), 1.71 (quin, $4 \mathrm{H}, J=7.5 \mathrm{~Hz}$ ), 1.42 (quin, 2H, $J=7.5 \mathrm{~Hz}$ ), 1.34 (t, $6 \mathrm{H}$, $J=7.1 \mathrm{~Hz}) .{ }^{13} \mathrm{C}$ NMR $\left(125 \mathrm{MHz}, \mathrm{DMSO}-d_{6}\right): \delta 165.0,136.7,130.1,129.7,128.8,60.4$, 49.2, 46.0, 24.3, 22.7, 13.7. IR $v_{\max }(\mathrm{KBr}): \mathrm{cm}^{-1} 3413$, 2937, 2908, 2797, 1717, 1617, 
1576, 1479, 1442, 1368, 1283, 1112, 1026, 858, 760, 703, 524. HRMS (FAB) calcd for $\mathrm{C}_{25} \mathrm{H}_{35} \mathrm{~N}_{2} \mathrm{O}_{4}{ }^{+}[\mathrm{M}-\mathrm{HCl}-\mathrm{Cl}]^{+}, m / z$ 427.2591; found, 427.2591.

\section{Bis-ammonium salt 7a}

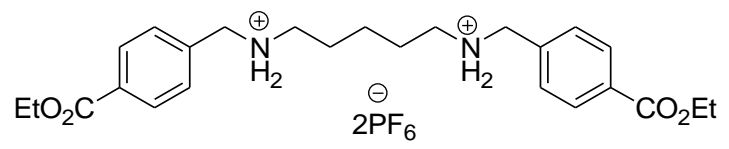

$\mathrm{NH}_{4} \mathrm{PF}_{6}(261 \mathrm{mg}, 1.60 \mathrm{mmol})$ was added to a suspension of the bis-ammonium salt 7c (100 mg, $0.200 \mathrm{mmol})$ in $\mathrm{H}_{2} \mathrm{O}(7 \mathrm{~mL})$ and acetone $(7 \mathrm{~mL})$ at room temperature. After stirring for $2 \mathrm{~h}$ at room temperature, the acetone was evaporated. The precipitate was collected by filtration and washed with $\mathrm{H}_{2} \mathrm{O}$ to afford a white solid $(97.8 \mathrm{mg}, 68 \%) .{ }^{1} \mathrm{H}$ NMR (500 MHz, DMSO- $\left.d_{6}\right): \delta 8.75$ (br s, 4H), 8.05-8.02 (m, 4H), 7.64-7.59 (m, 4H), 4.32 (q, 4H, $J=7.1 \mathrm{~Hz}$ ), 4.23 (br s, 4H), 2.95-2.86 (m, 4H), 1.59 (quin, 4H, $J=7.7 \mathrm{~Hz}$ ), $1.37-1.29$ (m, 8H). ${ }^{13} \mathrm{C}$ NMR (125 MHz, DMSO- $\left.d_{6}\right): \delta 165.5,137.2,130.5,130.2,129.6$, 61.1, 49.7, 46.6, 25.0, 23.1, 14.2. IR $v_{\max }(\mathrm{KBr}): \mathrm{cm}^{-1}$ 3258, 3236, 2983, 2942, 2803, 1717, 1581, 1432, 1368, 1283, 1190, 1112, 1025, 839, 560. HRMS (FAB) calcd for $\mathrm{C}_{25} \mathrm{H}_{35} \mathrm{~N}_{2} \mathrm{O}_{4}{ }^{+}\left[\mathrm{M}-\mathrm{HPF}_{6}-\mathrm{PF}_{6}\right]^{+}, m / z$ 427.2591; found, 427.2601.

\section{Bis-ammonium salt $7 \mathbf{b}$}

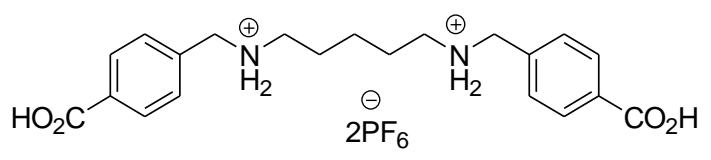

1.0 $\mathrm{M} \mathrm{NaOH}(\mathrm{aq})(4.0 \mathrm{~mL}, 4.0 \mathrm{mM})$ was added to a suspension of the bis-ammonium salt $7 \mathbf{a}(0.240 \mathrm{~g}, 0.490 \mathrm{mmol})$ in $\mathrm{MeOH}(8 \mathrm{~mL})$ at room temperature and then the mixture was stirred at room temperature for $4 \mathrm{~h}$. The solvent was evaporated and then excess $55 \%$ $\mathrm{HPF}_{6}$ (aq) was added to the residue at $0{ }^{\circ} \mathrm{C}$. The mixture was stirred for $2 \mathrm{~h}$ at room temperature. The precipitate was collected by filtration and washed with $\mathrm{H}_{2} \mathrm{O}$ to afford a white solid (0.170 g, 62\%). ${ }^{1} \mathrm{H}$ NMR (500 MHz, DMSO- $d_{6}$ ): $\delta 8.77$ (br s, 4H), 8.03-7.98 $(\mathrm{m}, 4 \mathrm{H}), 7.62-7.57(\mathrm{~m}, 4 \mathrm{H}), 4.22(\mathrm{~s}, 4 \mathrm{H}), 2.90(\mathrm{t}, 4 \mathrm{H}, J=7.3 \mathrm{~Hz}$ ), 1.60 (quin, 4H, $J=7.3$ $\mathrm{Hz}$ ), 1.33 (quin, $2 \mathrm{H}, J=7.3 \mathrm{~Hz}$ ). ${ }^{13} \mathrm{C}$ NMR (125 MHz, DMSO- $\left.d_{6}\right): \delta 166.9,136.7,131.3$, 130.0, 129.7, 49.6, 46.5, 25.0, 23.0. IR $v_{\max }(\mathrm{KBr}): \mathrm{cm}^{-1}$ 3425, 2944, 2900, 2804, 1689, 1582, 1569, 1473, 1430, 1277, 1124, 1084, 740, 523. HRMS (FAB) calcd for $\mathrm{C}_{21} \mathrm{H}_{27} \mathrm{~N}_{2} \mathrm{O}_{4}{ }^{+}\left[\mathrm{M}-\mathrm{HPF}_{6}-\mathrm{PF}_{6}\right]^{+}, m / z$ 371.1965; found, 371.1979 .

\section{[2]Rotaxane 2}

The ammonium salt $\mathbf{7 b}(39.5 \mathrm{mg}, 59.6 \mu \mathrm{mol})$ was added to a solution of the bis-crown 
ether $1(50.0 \mathrm{mg}, 49.6 \mu \mathrm{mol})$ in $\mathrm{MeCN}(12 \mathrm{~mL})$ and $\mathrm{CHCl}_{3}(12 \mathrm{~mL})$. After stirring for 38 $\mathrm{h}$, diphenyldiazomethane $(21.4 \mathrm{mg}, 0.124 \mathrm{mmol})$ was added at room temperature and then the mixture was stirred for $24 \mathrm{~h}$. The solvent was evaporated and the residue purified through column chromatography $\left(\mathrm{SiO}_{2}\right.$; toluene/acetone, 3:1) to afford a powder, which was washed with hexane to give a colorless powder $(57.6 \mathrm{mg}, 58 \%) .{ }^{1} \mathrm{H} \mathrm{NMR}(600 \mathrm{MHz}$, $\left.\mathrm{CDCl}_{3}\right): \delta 7.92(\mathrm{~d}, 4 \mathrm{H}, J=8.3 \mathrm{~Hz}), 7.47(\mathrm{~d}, 4 \mathrm{H}, J=8.3 \mathrm{~Hz}), 7.46-7.30(\mathrm{~m}, 22 \mathrm{H}), 7.24-$ $7.13(\mathrm{~m}, 2 \mathrm{H}), 7.10(\mathrm{~s}, 2 \mathrm{H}), 6.98(\mathrm{~d}, 2 \mathrm{H}, J=2.4 \mathrm{~Hz}), 6.73(\mathrm{~d}, 2 \mathrm{H}, J=2.4 \mathrm{~Hz}), 6.73-6.69$ (m, 2H), 6.69-6.64 (m, 2H), 6.50-6.46 (m, 4H), 4.68-4.46 (m, 8H), 4.23-4.17 (m, 2H), 4.10-3.94 (m, 10H), 3.91-3.78 (m, 10H), 3.66-3.49 (m, 14H), 3.48-3.23 (m, 10H), 3.16$3.09(\mathrm{~m}, 2 \mathrm{H}), 1.60-1.49(\mathrm{~m}, 2 \mathrm{H}), 1.34(\mathrm{~s}, 18 \mathrm{H}), 1.20-1.06(\mathrm{~m}, 4 \mathrm{H}) .{ }^{13} \mathrm{C}$ NMR $(150 \mathrm{MHz}$, $\left.\mathrm{CDCl}_{3}\right): \delta 164.6,151.1,147.1,146.4,143.4,140.0,137.1,133.5,130.7,129.8,129.5$, 128.6, 128.1, 127.2, 127.1, 121.65, 121.61, 119.4, 112.1, 111.9, 109.1, 77.7, 73.0, 71.9, 71.1, 70.9, 70.8, 70.1, 70.0, 69.93, 69.91, 68.4, 68.2, 66.6, 51.7, 48.8, 34.7, 31.5, 26.0, 22.6. IR $v_{\max }(\mathrm{KBr}): \mathrm{cm}^{-1} 3156,3066,2951,2874,1722,1580,1505,1456,1264,1109$, 1058, 954, 840, 744, 703, 558. HRMS (MALDI, TOF) calcd. for $\mathrm{C}_{103} \mathrm{H}_{125} \mathrm{~N}_{2} \mathrm{O}_{20}{ }^{+}[\mathrm{M}-$ $\left.\mathrm{HPF}_{6}-\mathrm{PF}_{6}\right]^{+}, m / z$ 1709.8820; found, 1709.8859 .

\section{XRD structure determination}

A crystal suitable for XRD studies was analyzed using a Rigaku Saturn 724+ diffractometer with silicon monochromated synchrotron radiation $(\lambda=0.81078 \AA)$ at BL40XU beamline of SPring-8. The structure of 2 was solved using direct methods and refined by applying the full-matrix least-squares method. In subsequent refinement, the function $\Sigma \omega\left(F_{\mathrm{o}}{ }^{2}-{F_{\mathrm{c}}}^{2}\right)^{2}$ was minimized, where $F_{\mathrm{o}}$ and $F_{\mathrm{c}}$ are the observed and calculated structure factor amplitudes, respectively. The positions of non-hydrogen atoms were determined from difference Fourier electron density maps and were refined anisotropically. All calculations were performed using the Rigaku CrystalStructure crystallographic software package; illustrations were generated in the ORTEP style. Details of the structural determinations are provided in Figures 4, S12 and Table S1. CCDC 2105398 contains the supplementary crystallographic data for this paper.

\section{References}

1. Greenaway, K.; Dambruoso, P.; Ferrali, A.; Hazelwood, A. J.; Sladojevich, F.; Dixon, D. J. Synthesis 2011, 1880-1886.

2. Kimura, T.; Miyagawa, S.; Takaya, H.; Naito, M.; Tokunaga, Y. Chem. Asian J. 2020, 15, 3897-3903. 
We recorded VT NMR spectra of the bis-crown ether 1. Although we did not observe splitting of all of the signals, we did observe separation of three signals $(\mathrm{A}-\mathrm{C})$ upon decreasing the temperature (Figure S1). Signal A was split into two signals at temperatures below $-20{ }^{\circ} \mathrm{C}$ (at 4.14 and $4.24 \mathrm{ppm}$ at $-20{ }^{\circ} \mathrm{C}$ ); they coalesced at $-15^{\circ} \mathrm{C}$. We used the chemical shifts at $-20{ }^{\circ} \mathrm{C}$ and equation (1) to determine the half-life $(\tau)$ of racemization to be $7.2 \mathrm{~ms}$ at $-15^{\circ} \mathrm{C}$. We did not observe clear coalescence of the signals $\mathrm{B}$ and C. Instead, both signals gradually split at temperatures below $-40{ }^{\circ} \mathrm{C}$ for signal B and below $-50{ }^{\circ} \mathrm{C}$ for signal $\mathrm{C}$.

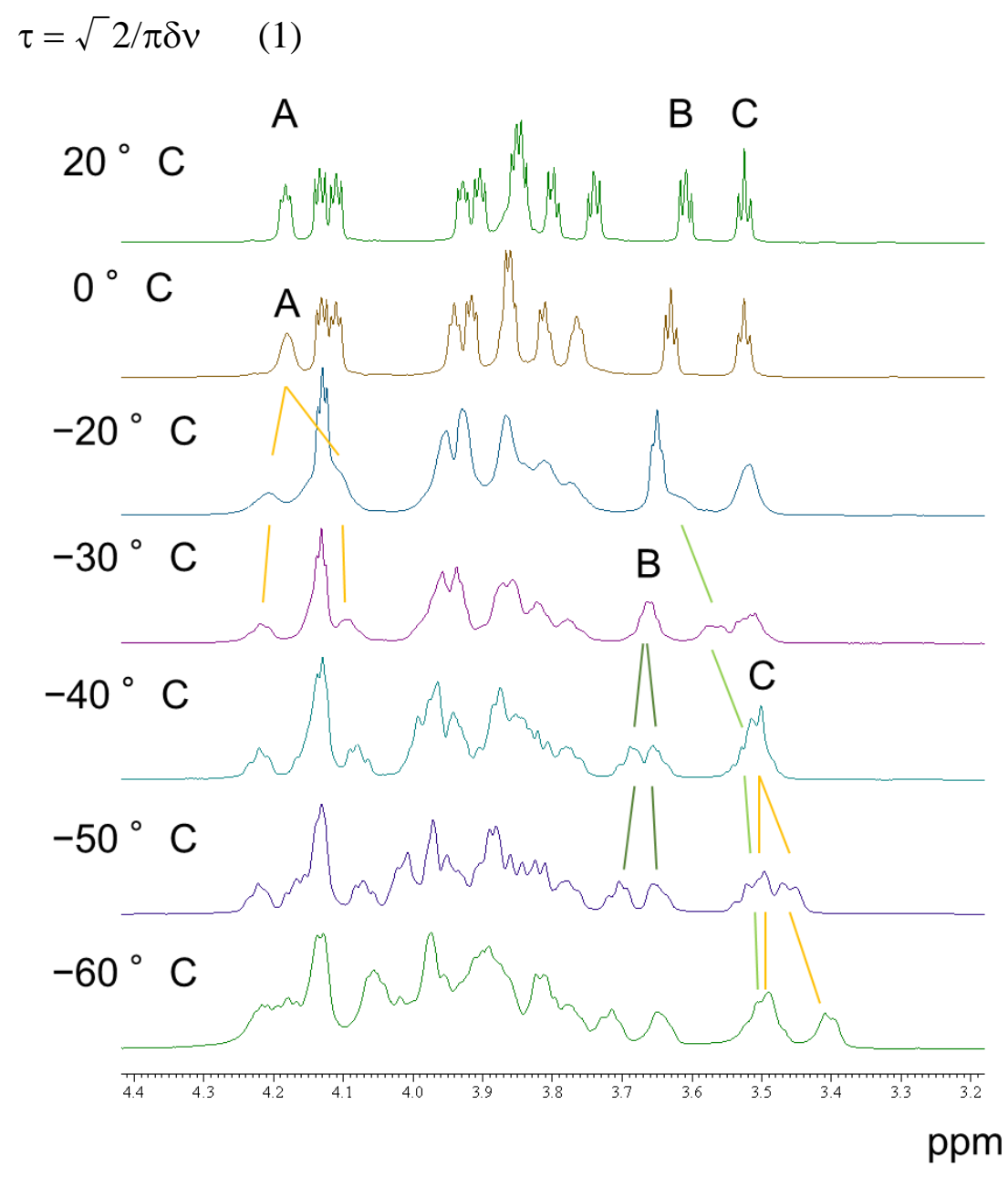

Figure S1. VT ${ }^{1} \mathrm{H}$ NMR spectra $\left(600 \mathrm{MHz}, \mathrm{CDCl}_{3}\right)$ of the bis-crown ether $\mathbf{1}$, recorded at temperatures from -60 to $+20{ }^{\circ} \mathrm{C}$. 
(a)

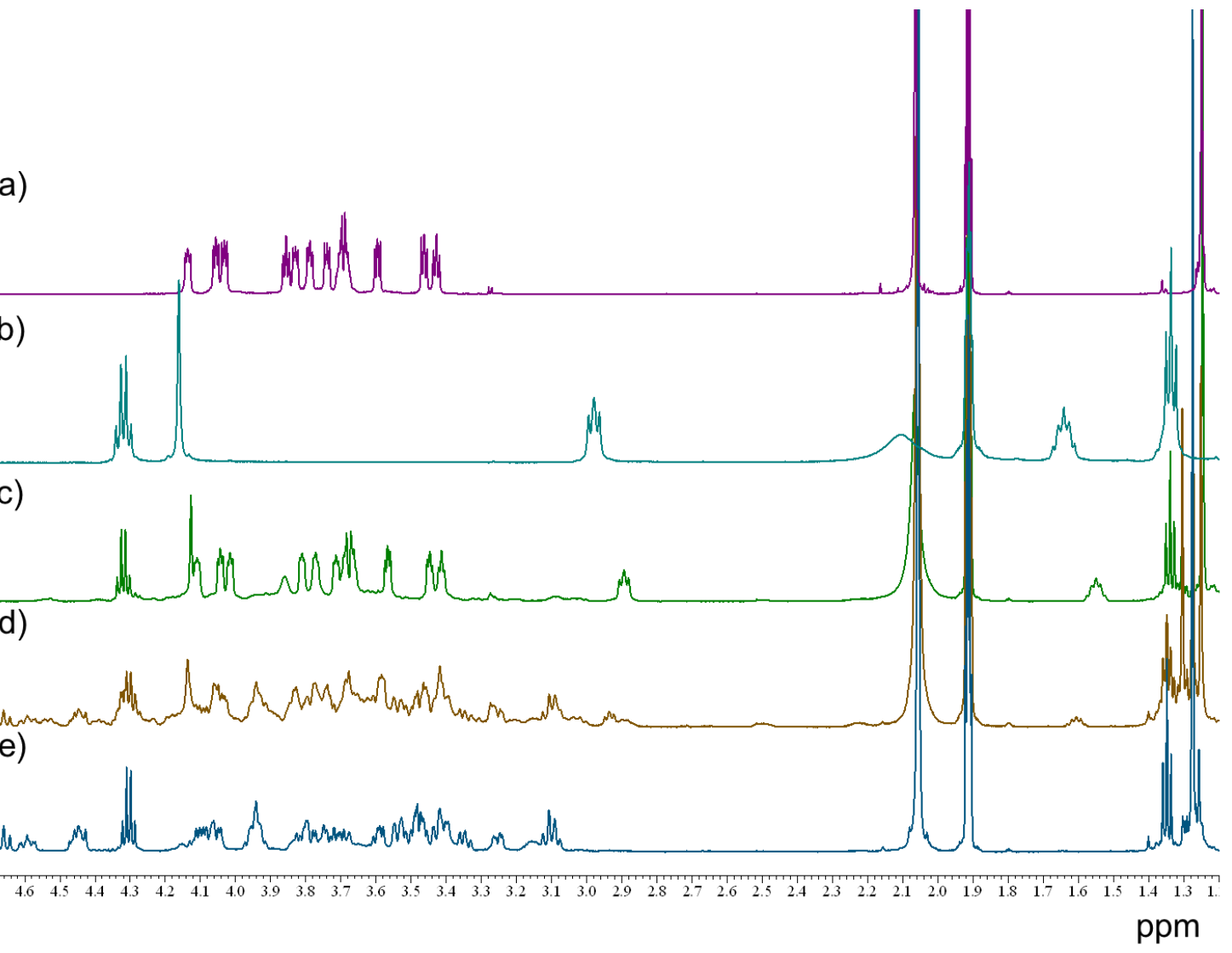

Figure S2a. Partial ${ }^{1} \mathrm{H}$ NMR spectra [600 MHz, $\left.\mathrm{CDCl}_{3} / \mathrm{CD}_{3} \mathrm{CN}(1: 1), 25{ }^{\circ} \mathrm{C}\right]$ of (a) the bis-crown ether $\mathbf{1}$, (b) the bis-ammonium salt 7a, (c) a 1:1 mixture of $\mathbf{1}(2 \mathrm{mM})$ and $7 \mathbf{a}(2$ $\mathrm{mM}$ ) after $15 \mathrm{~min}$, (d) $2 \mathrm{~h}$, and (e) $36 \mathrm{~h}$.

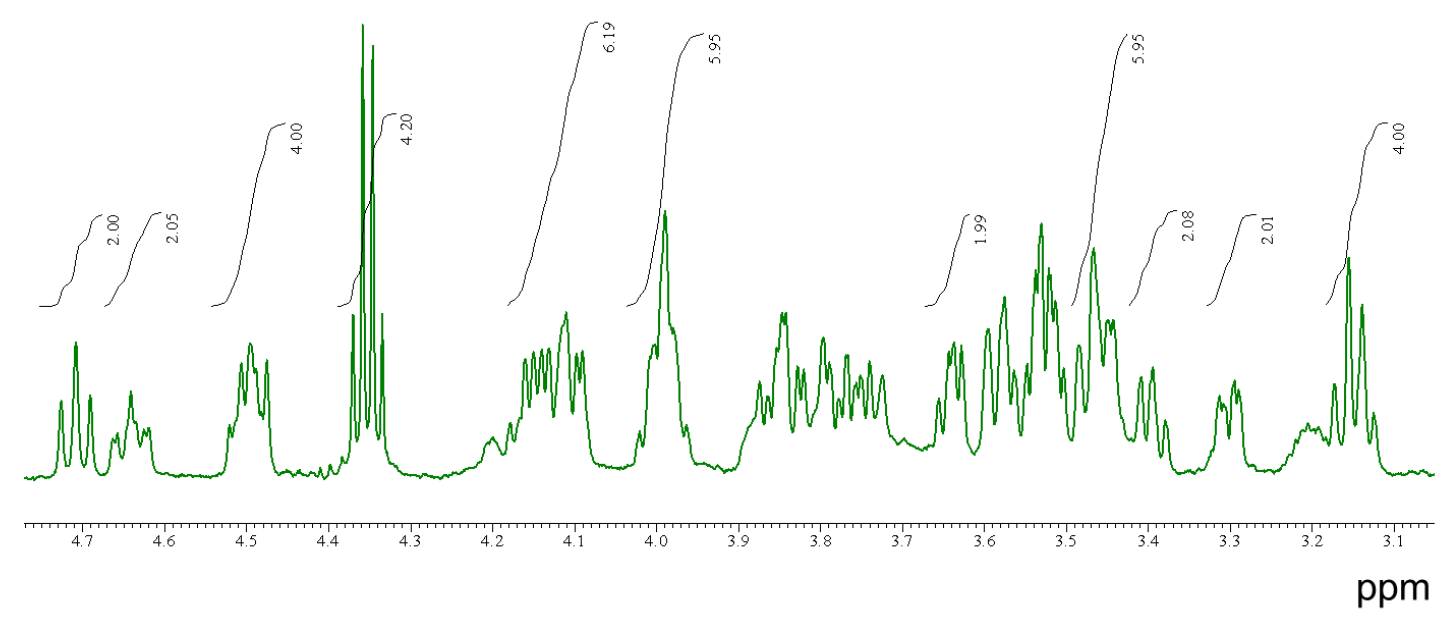

Figure S2b. Partial ${ }^{1} \mathrm{H}$ NMR spectra [600 MHz, $\mathrm{CDCl}_{3} / \mathrm{CD}_{3} \mathrm{CN}(1: 1), 25{ }^{\circ} \mathrm{C}$ ] of a $1: 1$ mixture of $1(2 \mathrm{mM})$ and $7 \mathbf{a}(2 \mathrm{mM})$ after $36 \mathrm{~h}$ [expanded spectrum of Figure S2a(e)]. 


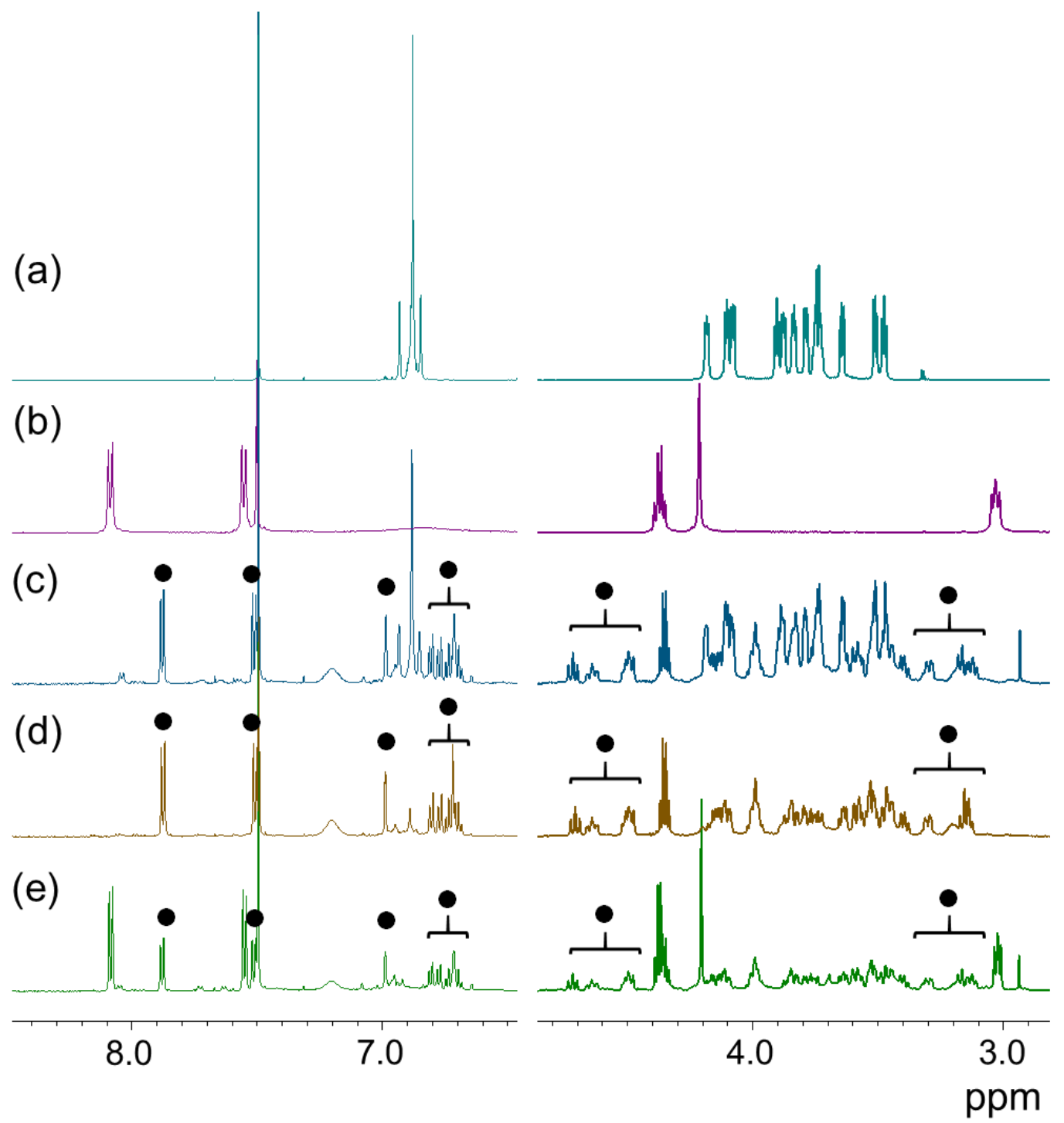

Figure S3. ${ }^{1} \mathrm{H}$ NMR spectra $\left[600 \mathrm{MHz}, \mathrm{CDCl}_{3} / \mathrm{CD}_{3} \mathrm{CN}(1: 1), 25{ }^{\circ} \mathrm{C}\right]$ of (a) bis-crown ether 1, (b) bis-ammonium salt 7a, (c) a mixture of 1 (2 $\mathrm{mM})$ and $7 \mathbf{a}(1 \mathrm{mM}),(\mathrm{d})$ a mixture of $\mathbf{1}(2 \mathrm{mM})$ and $\mathbf{7 a}(2 \mathrm{mM})$, (e) a mixture of $\mathbf{1}(1 \mathrm{mM})$ and $7 \mathbf{a}(2 \mathrm{mM})$. $\bullet$ : doubly threaded pseudorotaxane. 


\section{The relationship between signal patterns and symmetry of structure.}

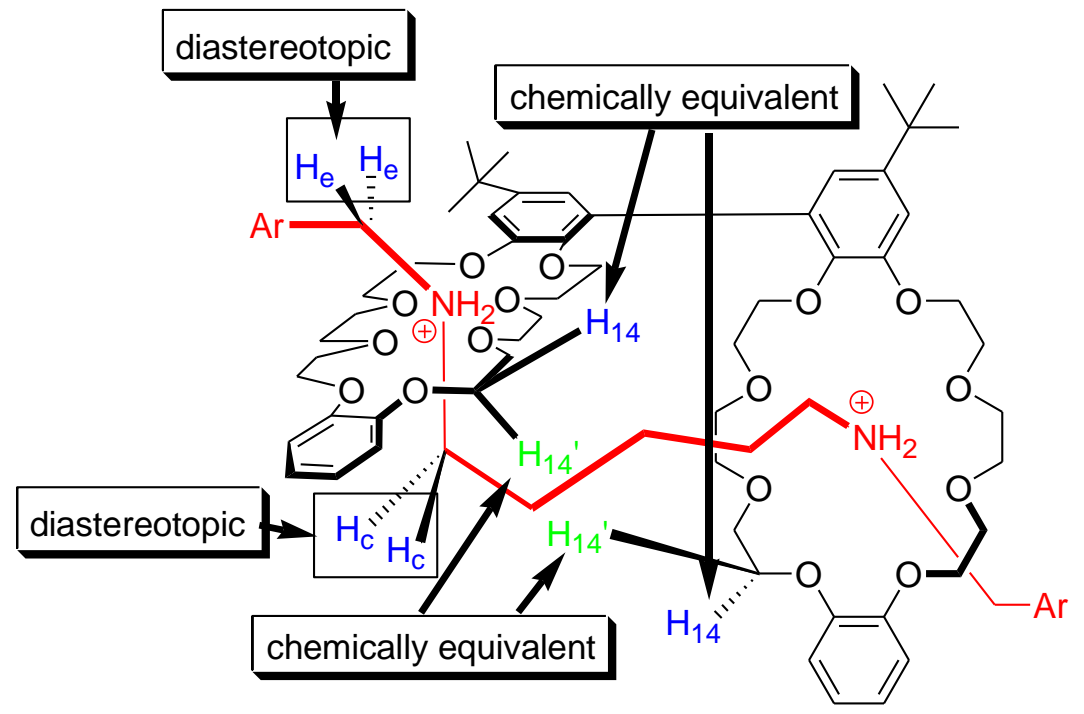

Figure S4. Structure of the chiral [2]rotaxane 2.

The chiral [2] rotaxane 2, $C_{2}$ symmetry, is shown in Figure $\mathrm{S} 4 . \mathrm{H}_{14}$ (blue) and $\mathrm{H}_{14}$ ' (green) in macrocyclic component are chemically non-equivalent. Protons $\mathrm{H}_{\mathrm{e}}$ (blue) in axle component are chemically equivalent, but diastereotopic.

\section{${ }^{1} \mathbf{H}$ NMR}

Aliphatic protons in the macrocyclic component (excluding ${ }^{\mathrm{t}} \mathrm{Bu}$ groups)

Total: 24 signals

The axle components has four chemically non-equivalent aliphatic protons, and three of them are diastereotopic (excluding diphenylmethyl ester moieties).

Total: seven signals

\section{${ }^{13}$ C NMR}

Aliphatic carbons in macrocyclic component (excluding ${ }^{\mathrm{t}} \mathrm{Bu}$ groups)

Total: 12 signals

Aliphatic carbons in the axle component (excluding diphenylmethyl ester moieties)

Total: four signals 

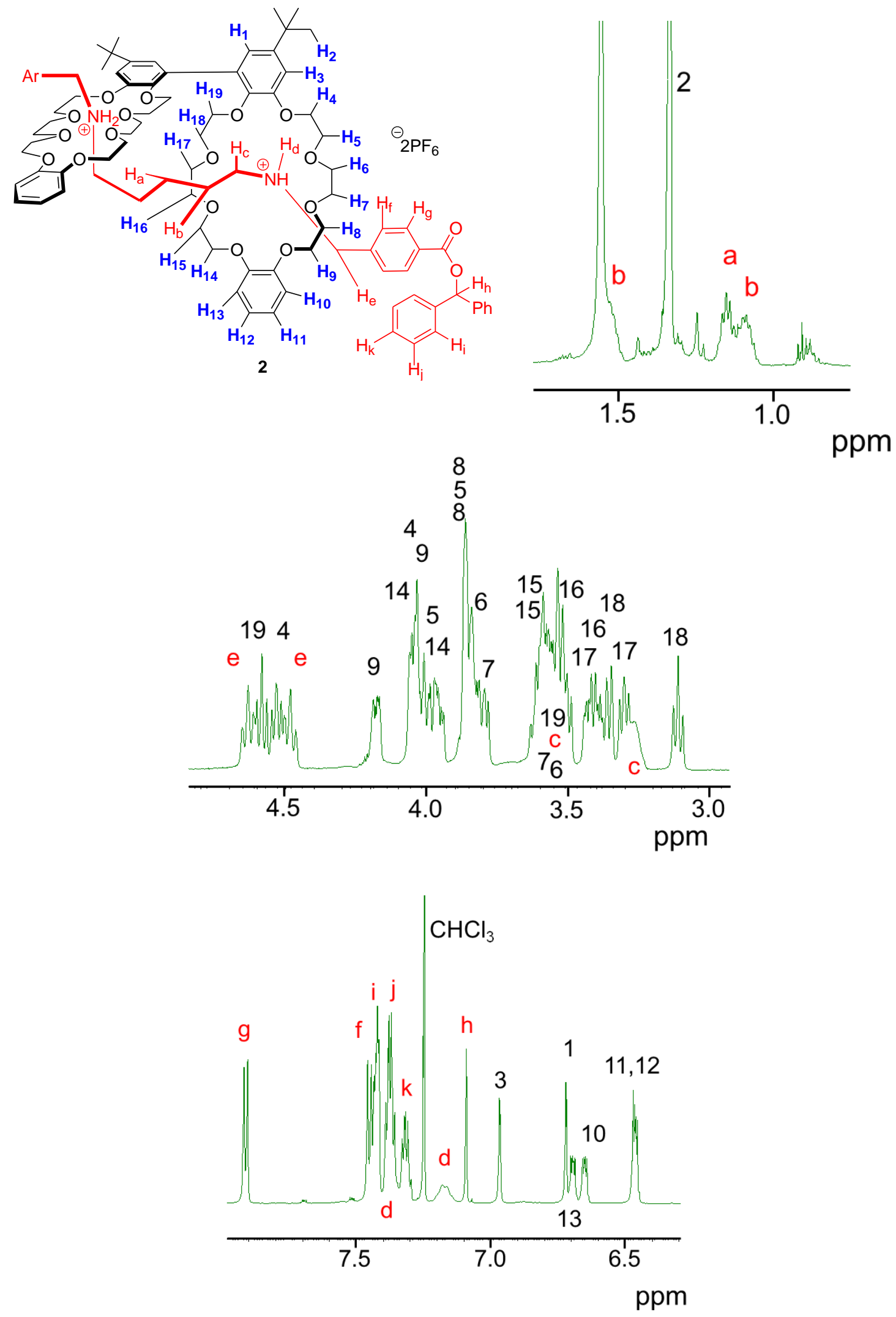

Figure S5. ${ }^{1} \mathrm{H}$ NMR spectrum $\left(600 \mathrm{MHz}, \mathrm{CDCl}_{3}, 25^{\circ} \mathrm{C}\right)$ of the [2] rotaxane 2. 

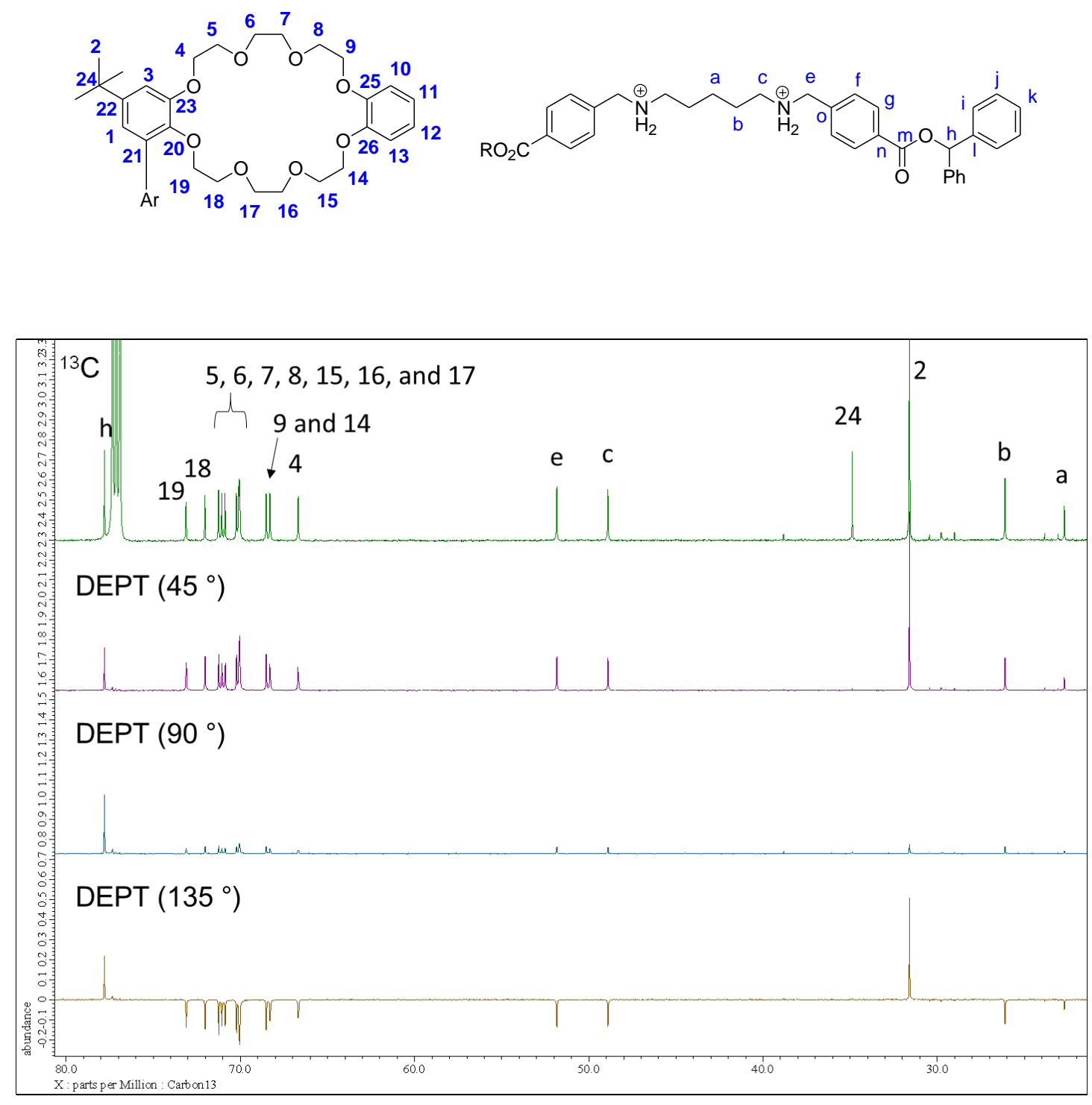

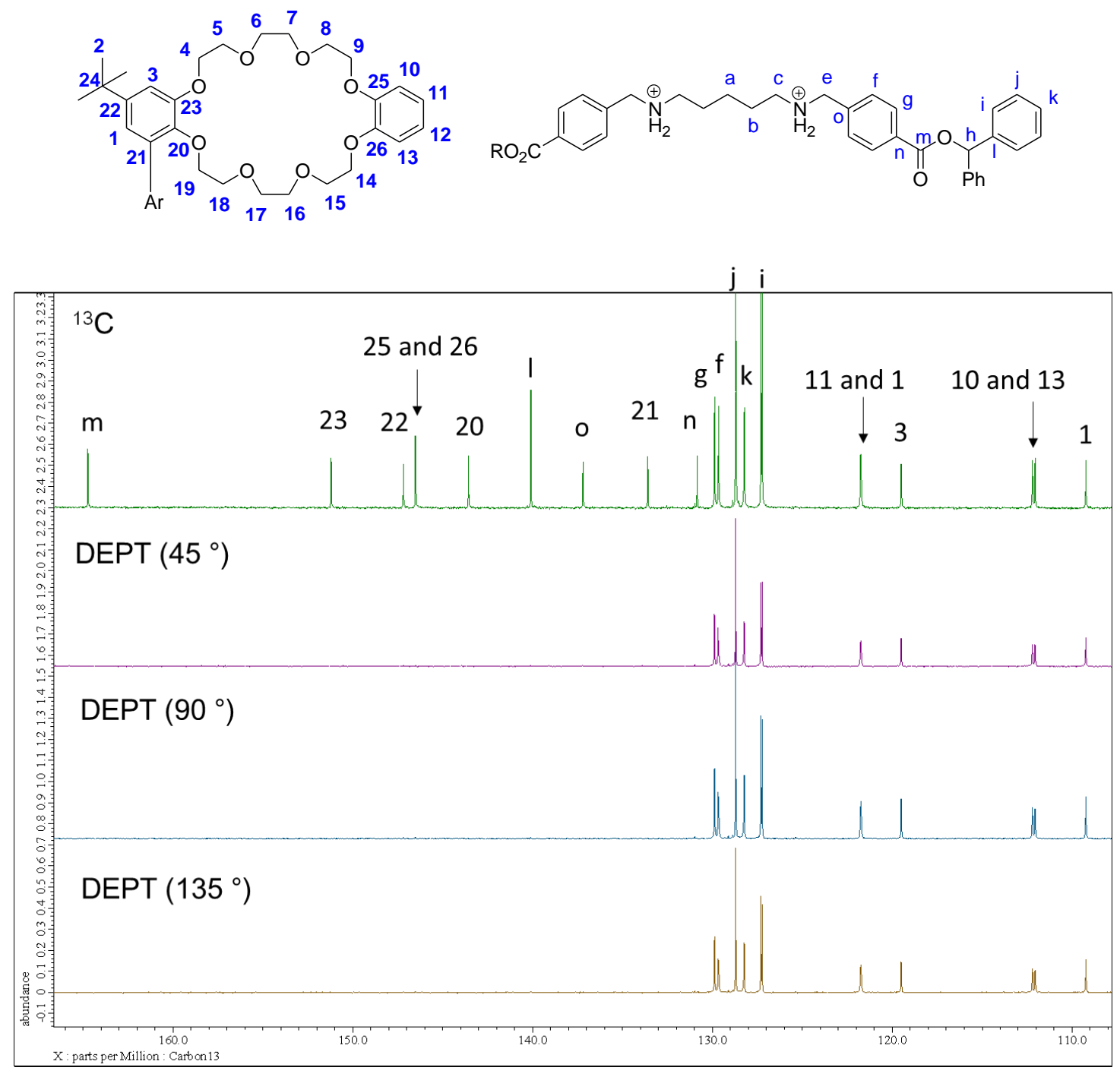

Figure S6. ${ }^{13} \mathrm{C}$ NMR and DEPT spectra $\left(150 \mathrm{MHz}, \mathrm{CDCl}_{3}, 25{ }^{\circ} \mathrm{C}\right)$ of the [2] rotaxane 2. 

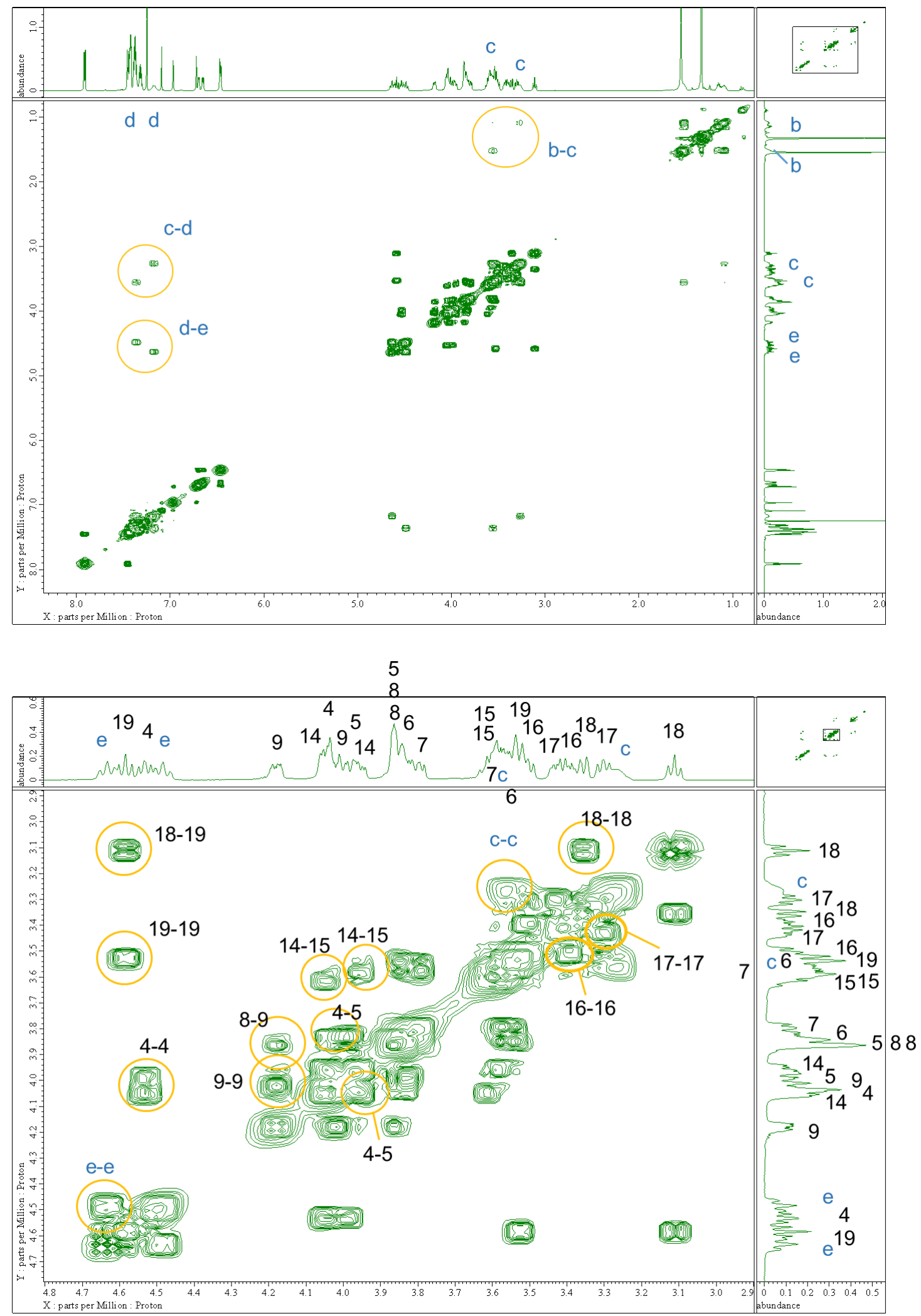


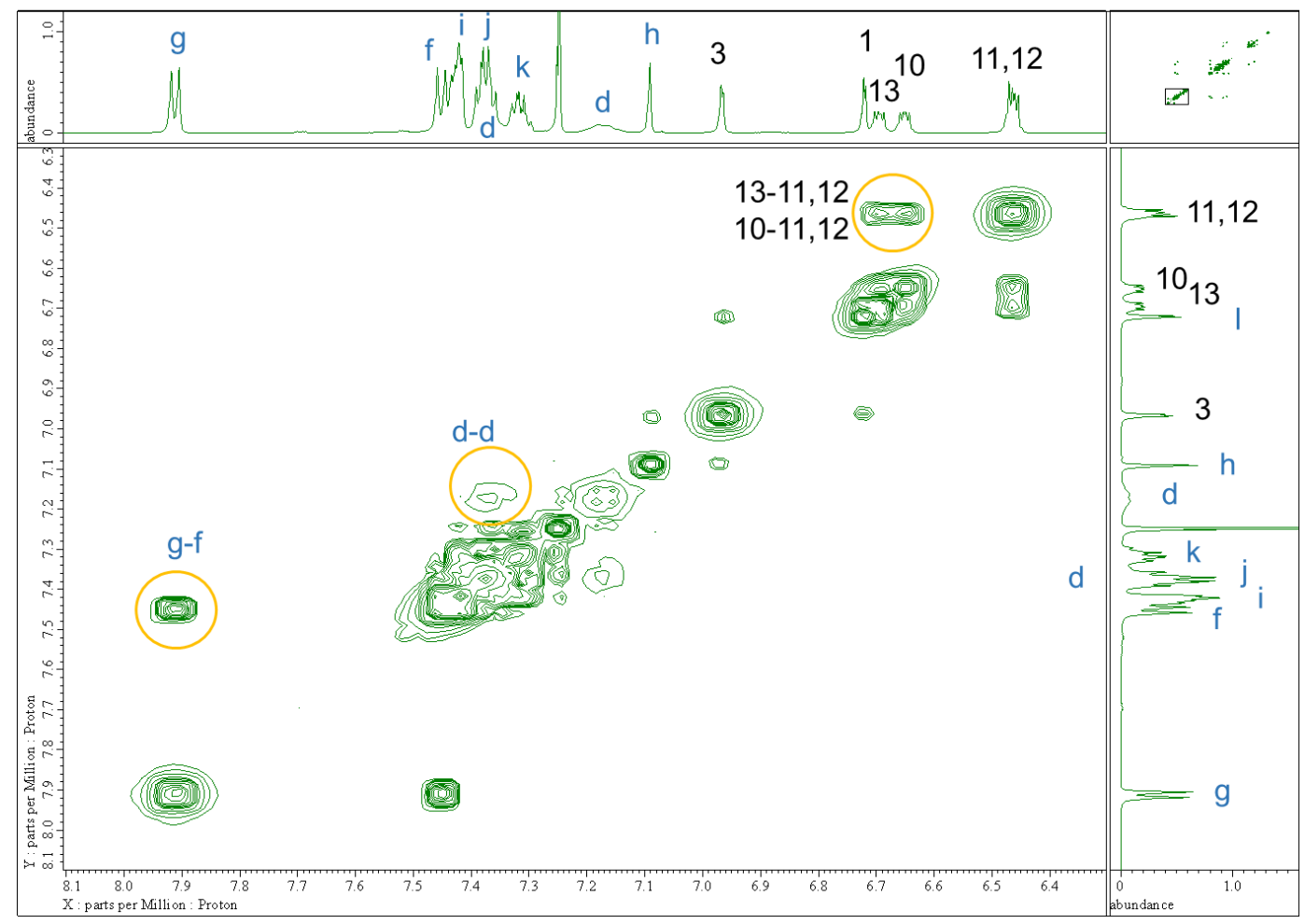

Figure S7. COSY spectrum $\left(600 \mathrm{MHz}, \mathrm{CDCl}_{3}, 25^{\circ} \mathrm{C}\right)$ of the [2]rotaxane 2. 

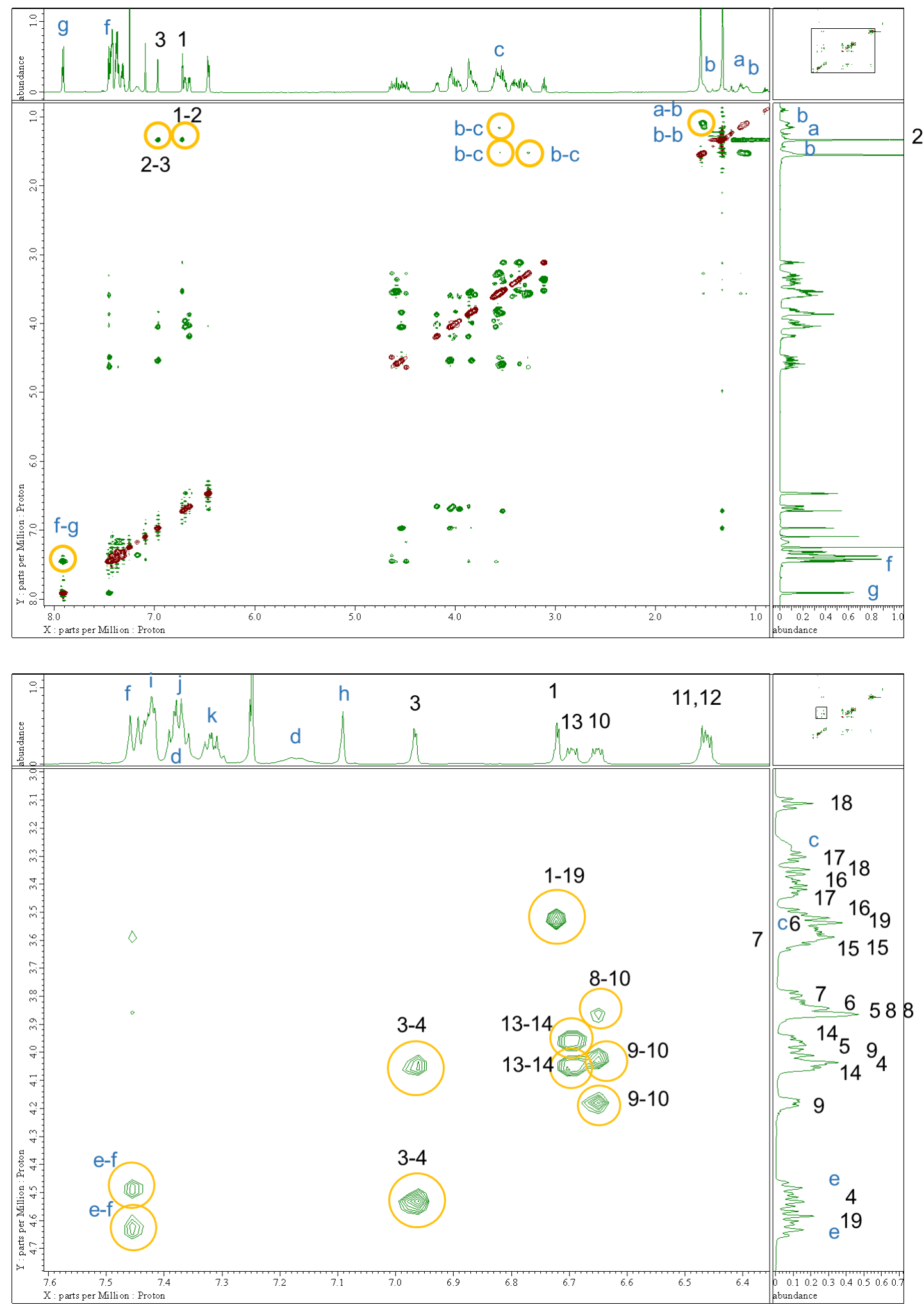


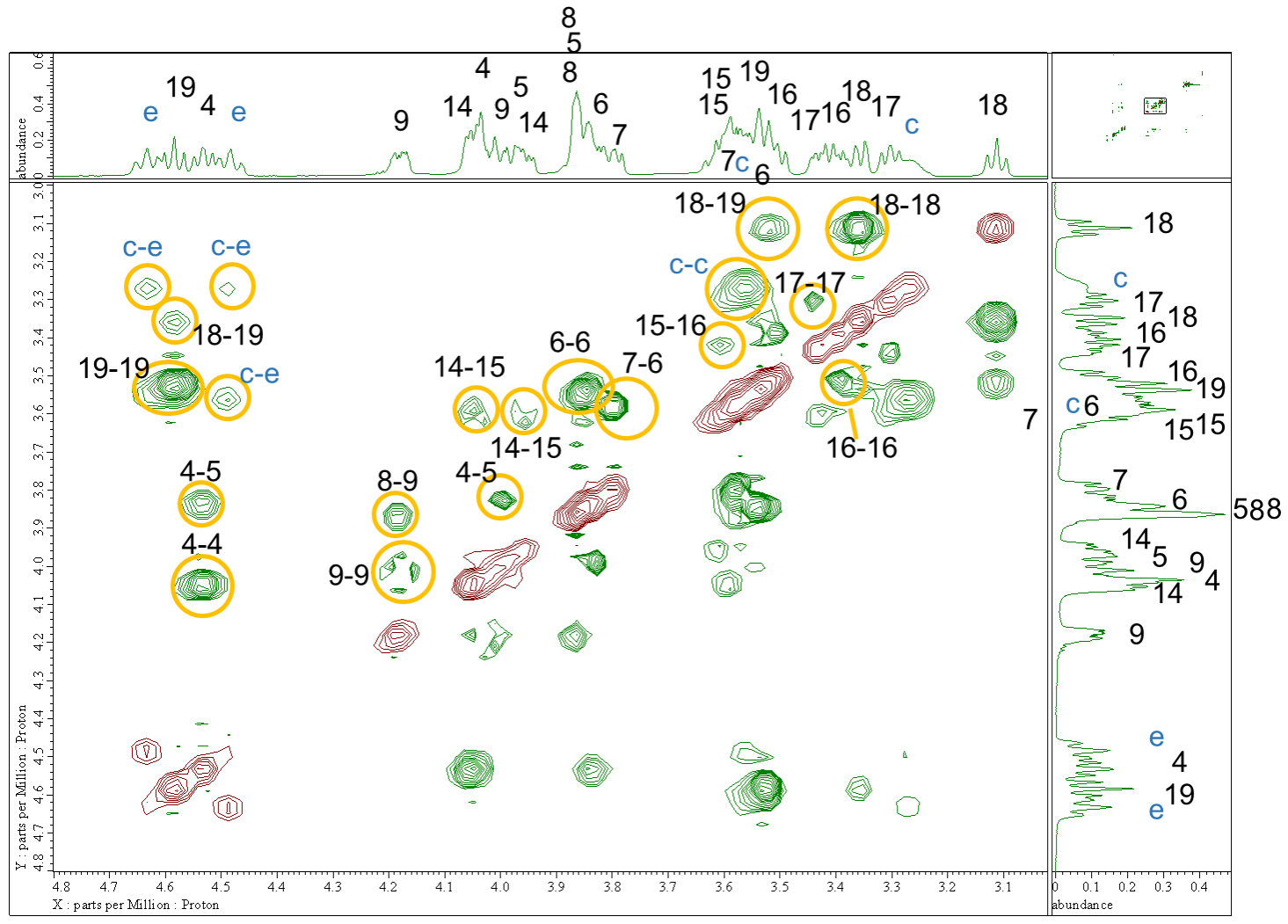

Figure S8. ROESY spectrum $\left(600 \mathrm{MHz}, \mathrm{CDCl}_{3}, 25^{\circ} \mathrm{C}\right)$ of the [2] rotaxane 2. 

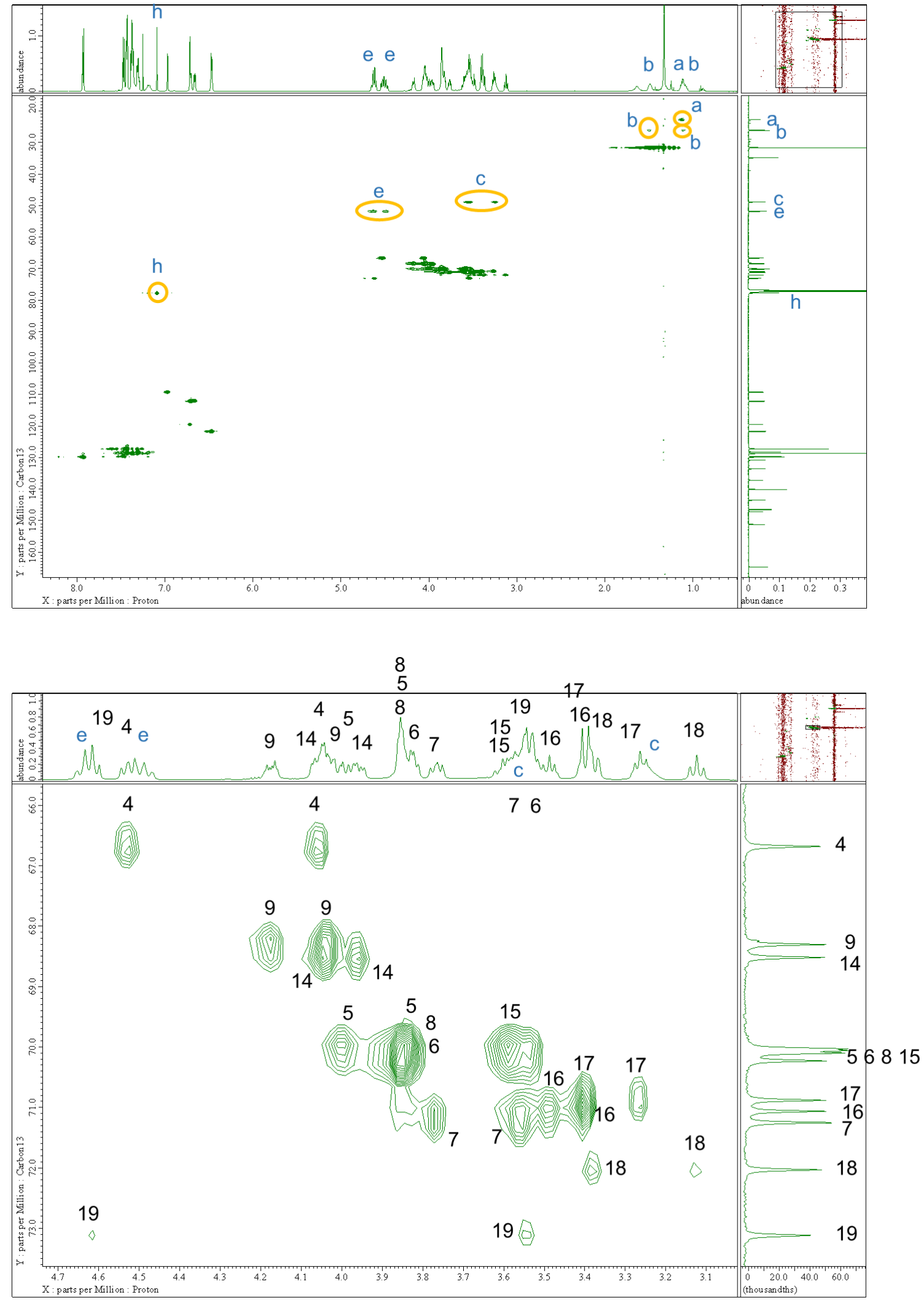


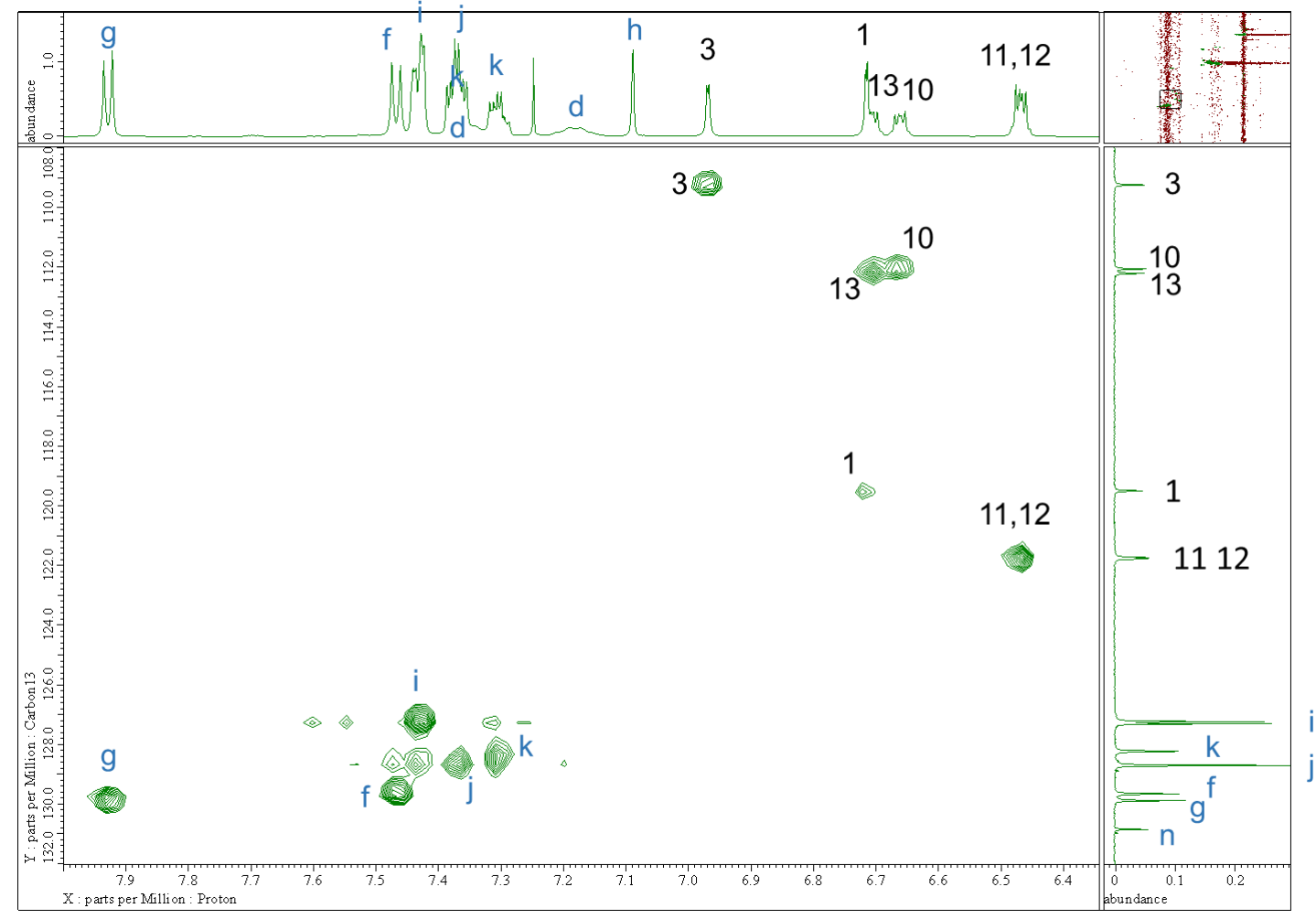

Figure S9. HSQC spectrum $\left(150 \mathrm{MHz}, \mathrm{CDCl}_{3}, 25^{\circ} \mathrm{C}\right)$ of the [2]rotaxane 2. 

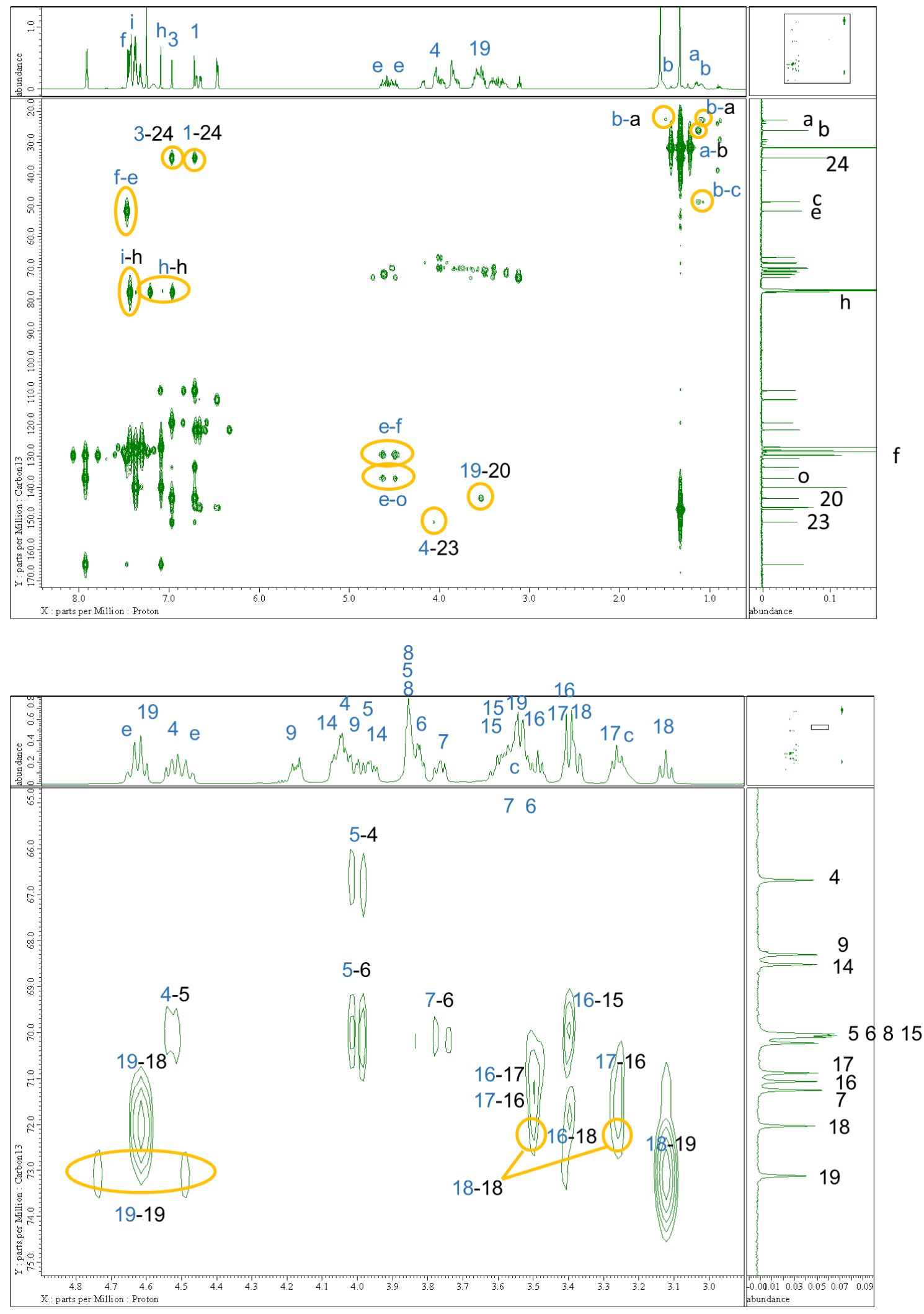


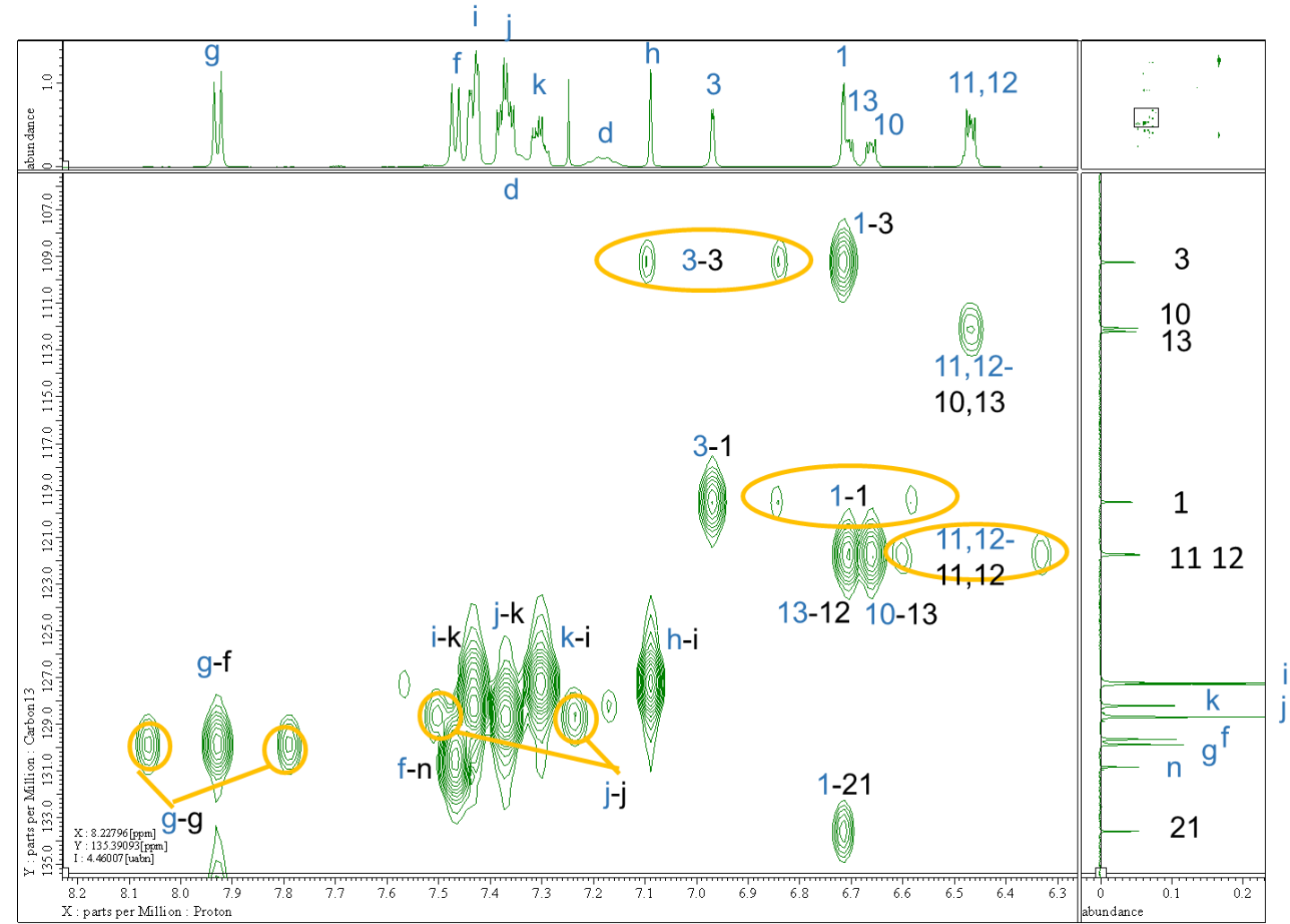

Figure S10. HMBC spectrum $\left(150 \mathrm{MHz}, \mathrm{CDCl}_{3}, 25^{\circ} \mathrm{C}\right)$ of the [2] rotaxane 2. 


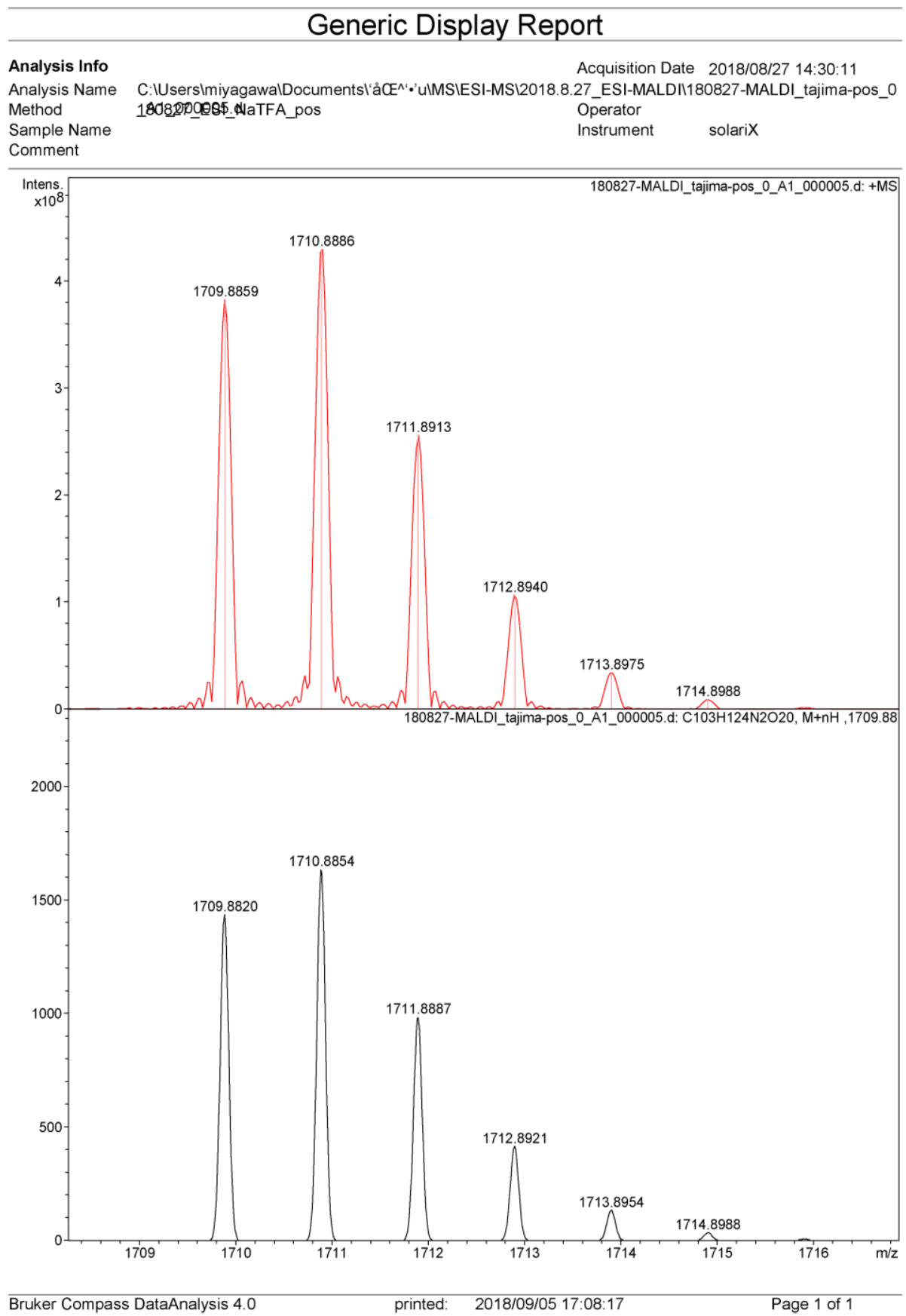

Figure S11. MALDI mass spectrum of the [2]rotaxane 2. Upper: Experimental isotopic pattern; lower: calculated isotopic pattern. 


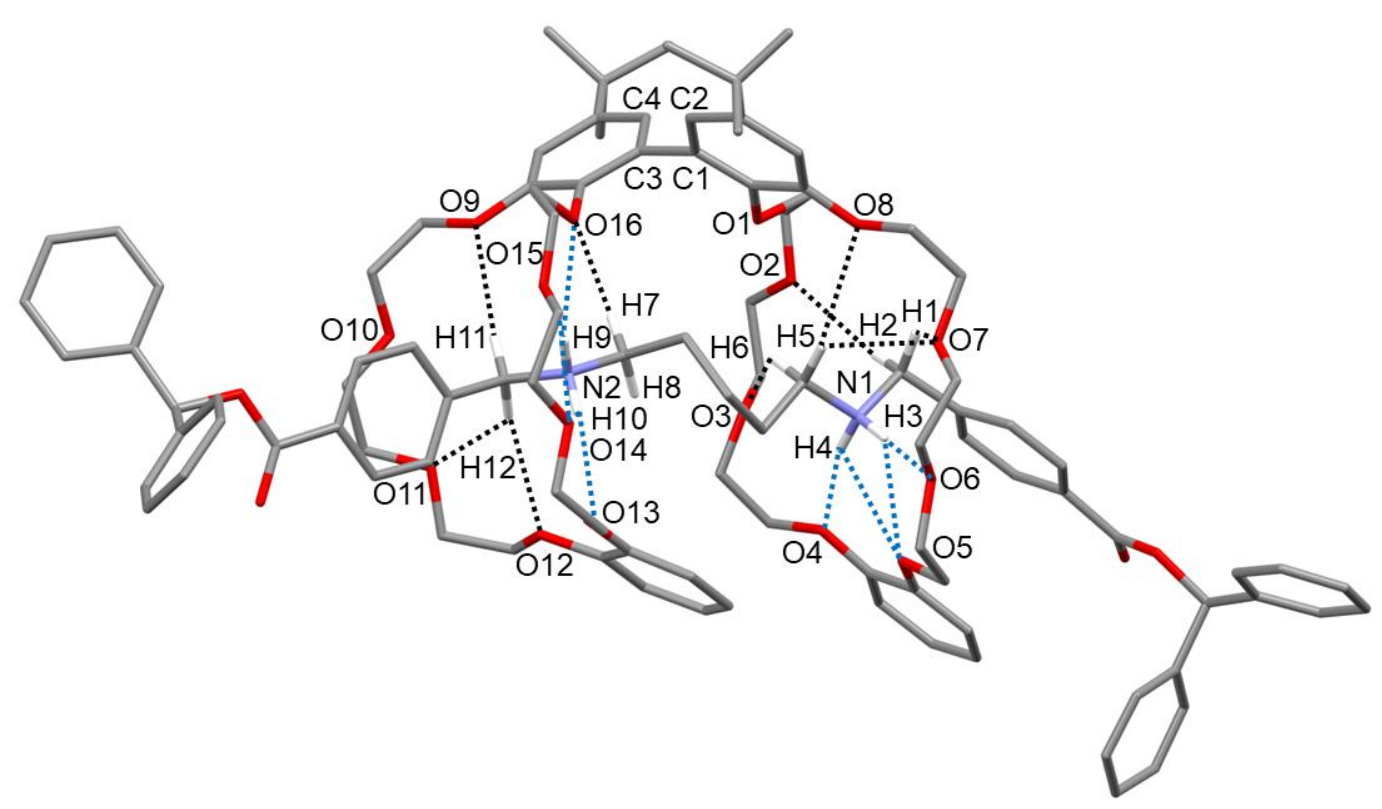

Figure S12a. Crystal structure of an enantiomer of the racemic [2]rotaxane 2. Hydrogen bonding distances of $\mathrm{NH} \cdots \mathrm{O}$ (blue dotted lines) are $2.61 \AA[\mathrm{H}(3) \cdots \mathrm{O}(5)], 2.08 \AA[\mathrm{H}(3) \cdots \mathrm{O}(6)], 2.19 \AA$ $[\mathrm{H}(4) \cdots \mathrm{O}(4)], 2.66 \AA[\mathrm{H}(4) \cdots \mathrm{O}(5)], 2.68 \AA[\mathrm{H}(9) \cdots \mathrm{O}(14)], 1.97 \AA[\mathrm{H}(9) \cdots \mathrm{O}(15)], 2.59 \AA$ $[\mathrm{H}(9) \cdots \mathrm{O}(16)], 2.22 \AA[\mathrm{H}(10) \cdots \mathrm{O}(13)], 2.33 \AA[\mathrm{H}(10) \cdots \mathrm{O}(14)]$, and $\mathrm{CH} \cdots \mathrm{O}$ (black dotted lines) are $2.67 \AA[\mathrm{H}(1) \cdots \mathrm{O}(7)], 2.38 \AA[\mathrm{H}(2) \cdots \cdot \mathrm{O}(2)], 2.55 \AA[\mathrm{H}(5) \cdots \cdot \mathrm{O}(7)], 2.70 \AA[\mathrm{H}(5) \cdots \cdot \mathrm{O}(8)], 2.58 \AA$ $[\mathrm{H}(6) \cdots \mathrm{O}(3)], 2.49 \AA[\mathrm{H}(7) \cdots \mathrm{O}(16)], 2.48 \AA[\mathrm{H}(11) \cdots \mathrm{O}(9)], 2.42 \AA[\mathrm{H}(12) \cdots \mathrm{O}(11)], 2.54 \AA$ $[\mathrm{H}(12) \cdots \mathrm{O}(12)]$. Hydrogen atoms, $\mathrm{CHCl}_{3}$ molecules and $\mathrm{PF}_{6}{ }^{-}$anions are omitted for clarity.

(a)

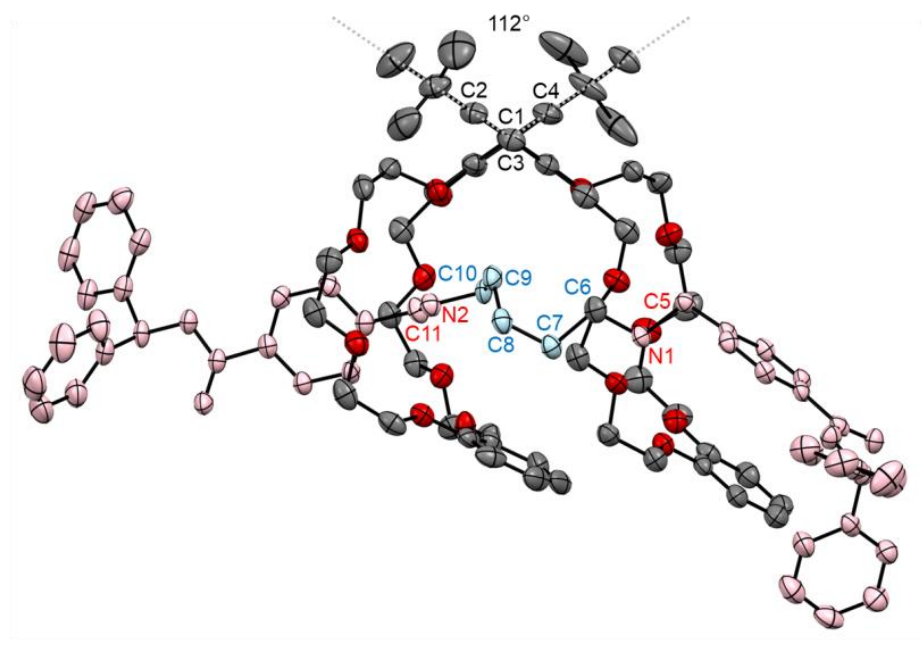

(b)

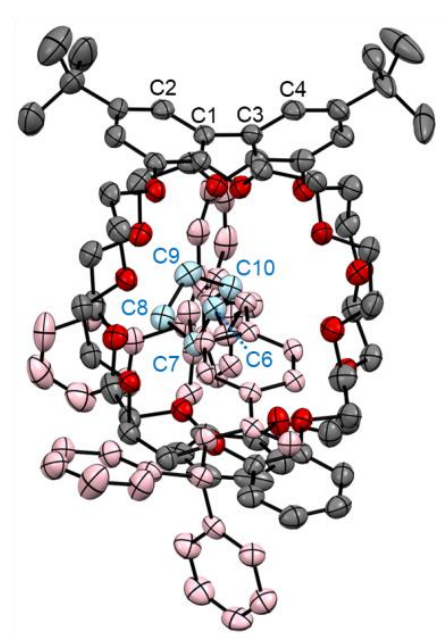

Figure S12b. Crystal structure of an enantiomer of the racemic [2] rotaxane 2. (a) Side and (b) front views. Hydrogen atoms, $\mathrm{CHCl}_{3}$ molecules and $\mathrm{PF}_{6}{ }^{-}$anions are omitted for clarity. Thermal ellipsoids are displayed at the $50 \%$ probability level. The axle component is colored in pale blue and pale red. 
Table S1. Crystal Data and Structure Refinement Details for $\mathbf{2} \cdot 4 \mathrm{CHCl}_{3}$

\begin{tabular}{ll}
\hline Parameter & $2 \cdot 4 \mathrm{CHCl}_{3}$ \\
\hline Formula & $\mathrm{C}_{107} \mathrm{H}_{130} \mathrm{Cl}_{12} \mathrm{~F}_{12} \mathrm{~N}_{2} \mathrm{O}_{20} \mathrm{P}_{2}$ \\
Formula weight & 2479.57 \\
Temperature & $-100{ }^{\circ} \mathrm{C}$ \\
Crystal color, habit & Colorless, block \\
Crystal size / mm & $0.010 \times 0.010 \times 0.010$ \\
Crystal system & Triclinic \\
Space group & $P-1(\# 2)$ \\
$a / \AA$ & $19.4136(4)$ \\
$b / \AA$ & $25.6413(5)$ \\
$c / \AA$ & $28.0214(5)$ \\
$\alpha /$ deg & $81.9639(11)$ \\
$\beta /$ deg & $74.2949(11)$ \\
$\gamma /$ deg & $73.6248(11)$ \\
$V / \AA$ & $12852.9(4)$ \\
$Z$ & 4 \\
$D_{\text {calcd }} / \mathrm{g} \mathrm{cm}{ }^{-3}$ & 1.281 \\
$F(000)$ & 5152.00 \\
$2 \theta_{\text {max }} /$ deg & 58.5 \\
No. of reflns meads & 137643 \\
No. of obsd reflns & 46934 \\
No. of variables & 2791 \\
$R_{1}[I>2 \sigma(I)]^{a}$ & 0.1155 \\
$R_{2}(\text { all reflns })^{b}$ & 0.3411 \\
\hline$R_{1}=\Sigma\left(\left|F_{\mathrm{o}}\right|-\left|F_{\mathrm{c}}\right|\right) / \Sigma\left(\left|F_{\mathrm{o}}\right|\right) .{ }^{b} w R_{2}=\left\{\Sigma\left[w\left(F_{\mathrm{o}}{ }^{2}-F_{\mathrm{c}}{ }^{2}\right)^{2}\right] / \Sigma w\left(F_{\mathrm{o}}{ }^{2}\right)^{2}\right\}^{1 / 2}$. \\
\hline
\end{tabular}



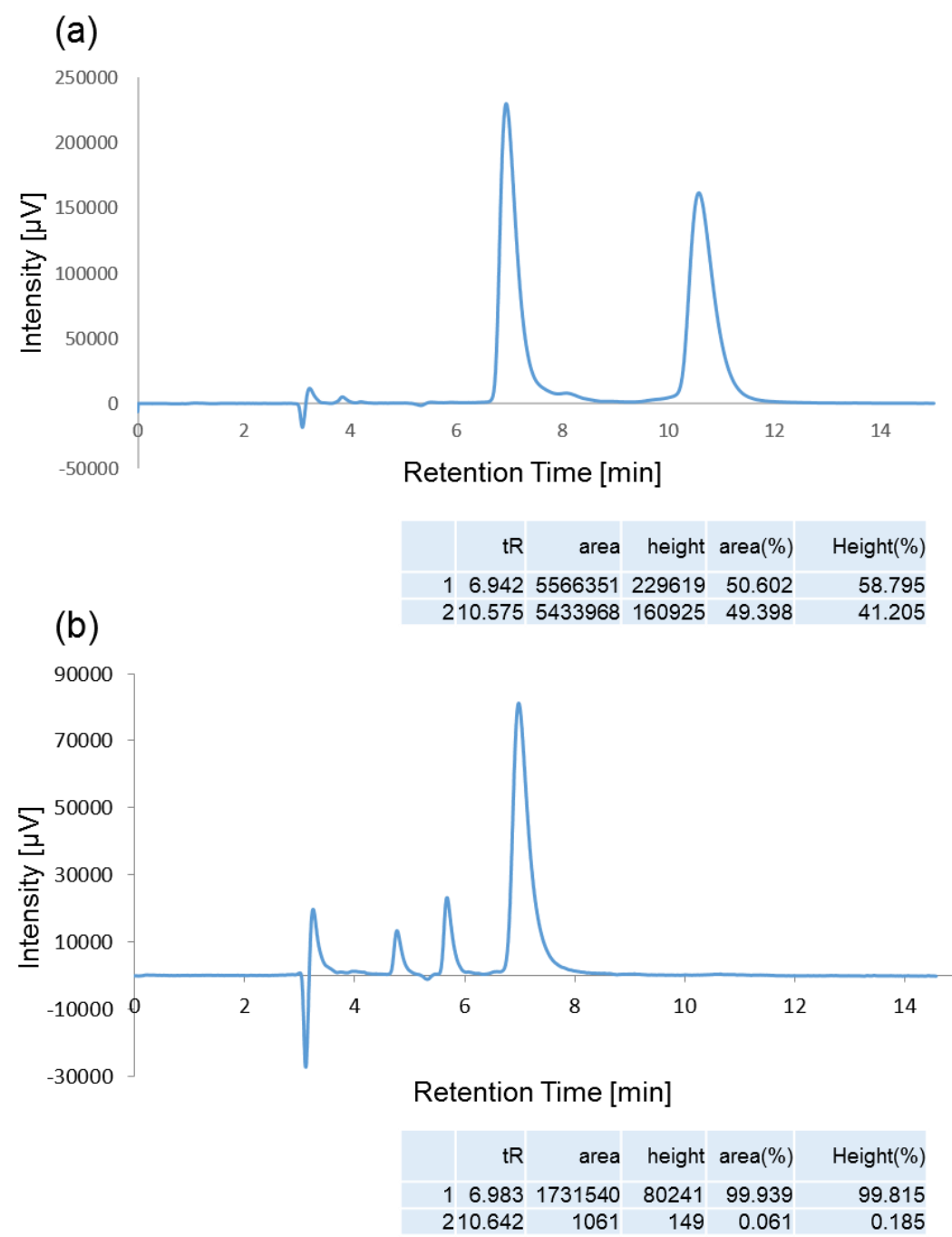

(c)
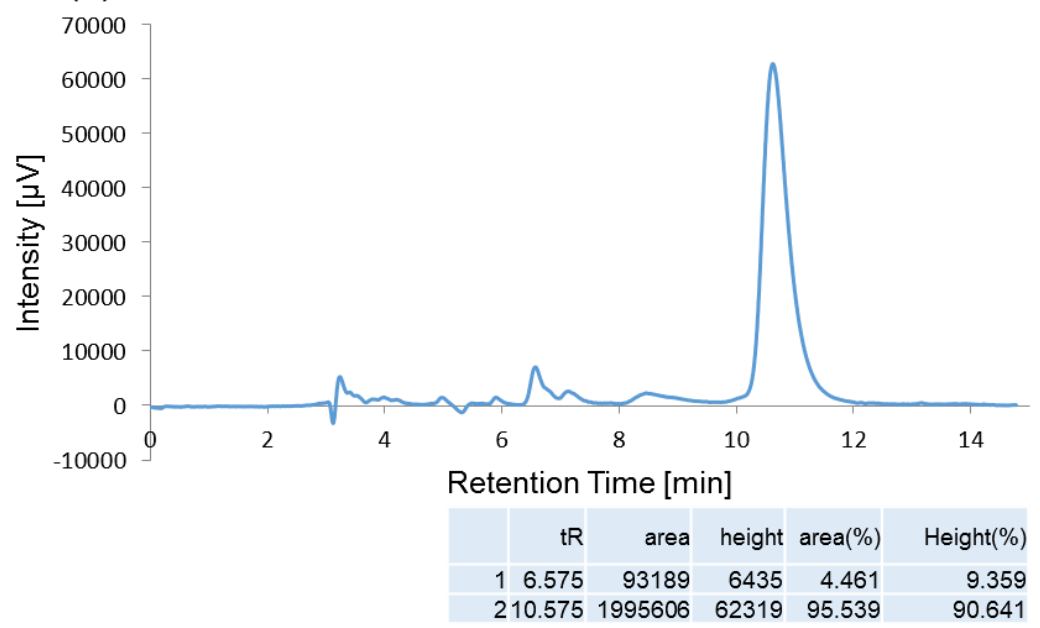

Figure S13. Chiral HPLC analysis of the [2]rotaxane 2. (a) Racemic mixture; (b, c) the two enantiomers of $\mathbf{2}$ after separation. 
HPLC conditions

Eluent: hexane: $\mathrm{CHCl}_{3}: \mathrm{TFA}:$ diethylamine $=50: 50: 0.1: 0.1$

Stationary phase: CHIRALPAK IA3

Detection: $274 \mathrm{~nm}$

Temperature: room temperature

Flow rate: $1.0 \mathrm{~mL} / \mathrm{min}$ 


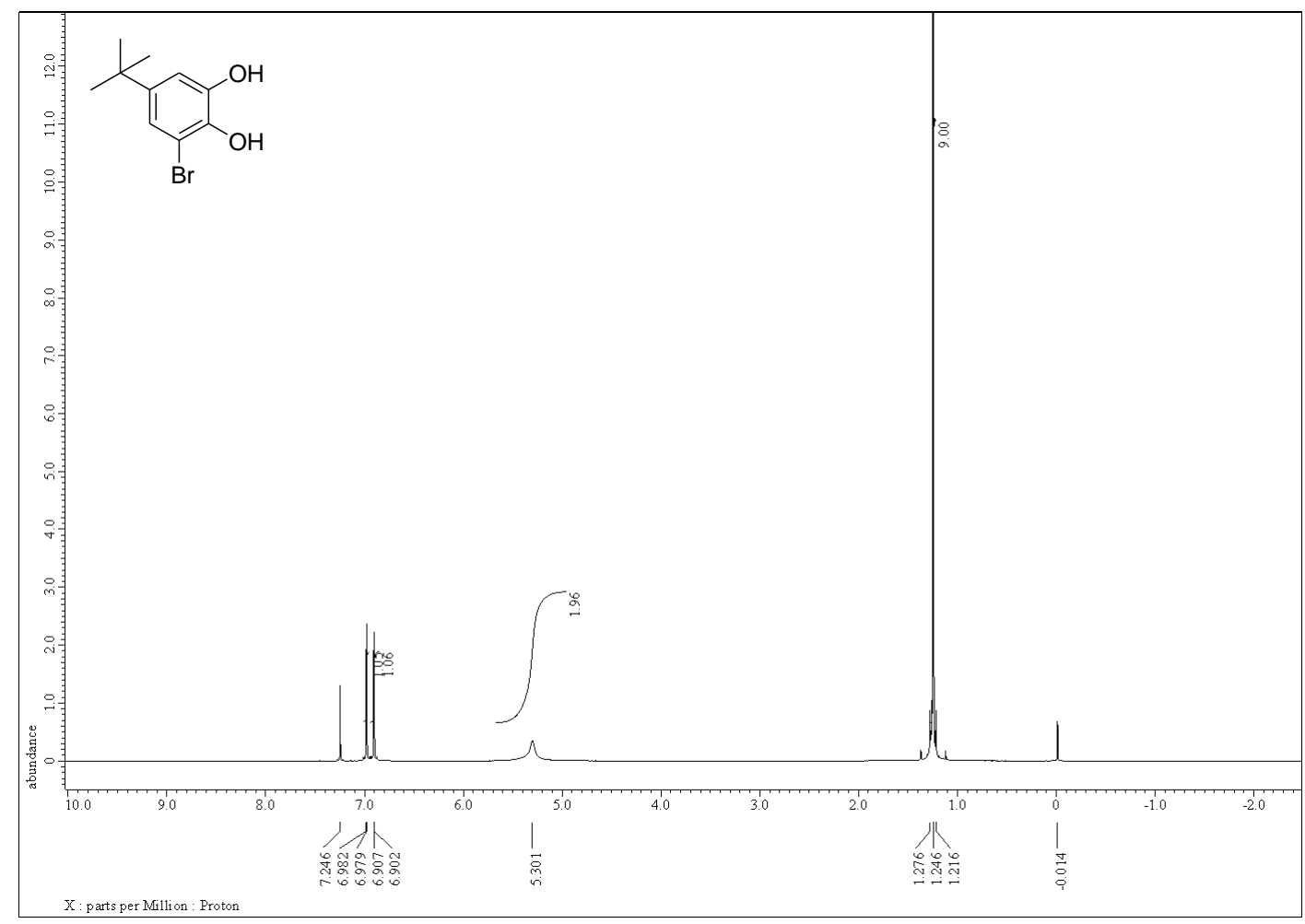

Figure S14a. ${ }^{1} \mathrm{H}$ NMR $\left(500 \mathrm{MHz}, \mathrm{CDCl}_{3}\right)$ spectrum of compound 4.

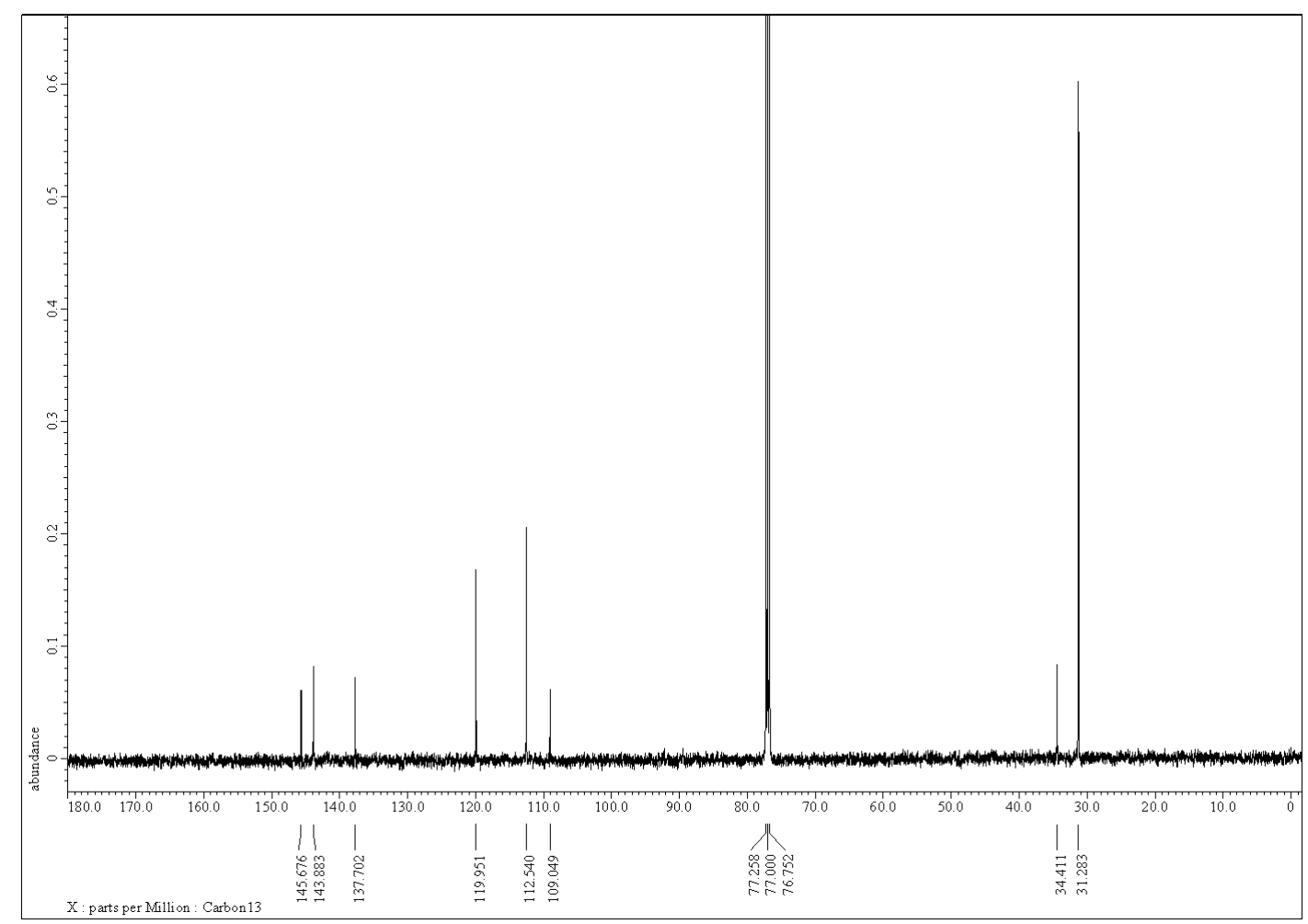

Figure S14b. ${ }^{13} \mathrm{C}$ NMR (125 MHz, $\left.\mathrm{CDCl}_{3}\right)$ spectrum of compound 4. 


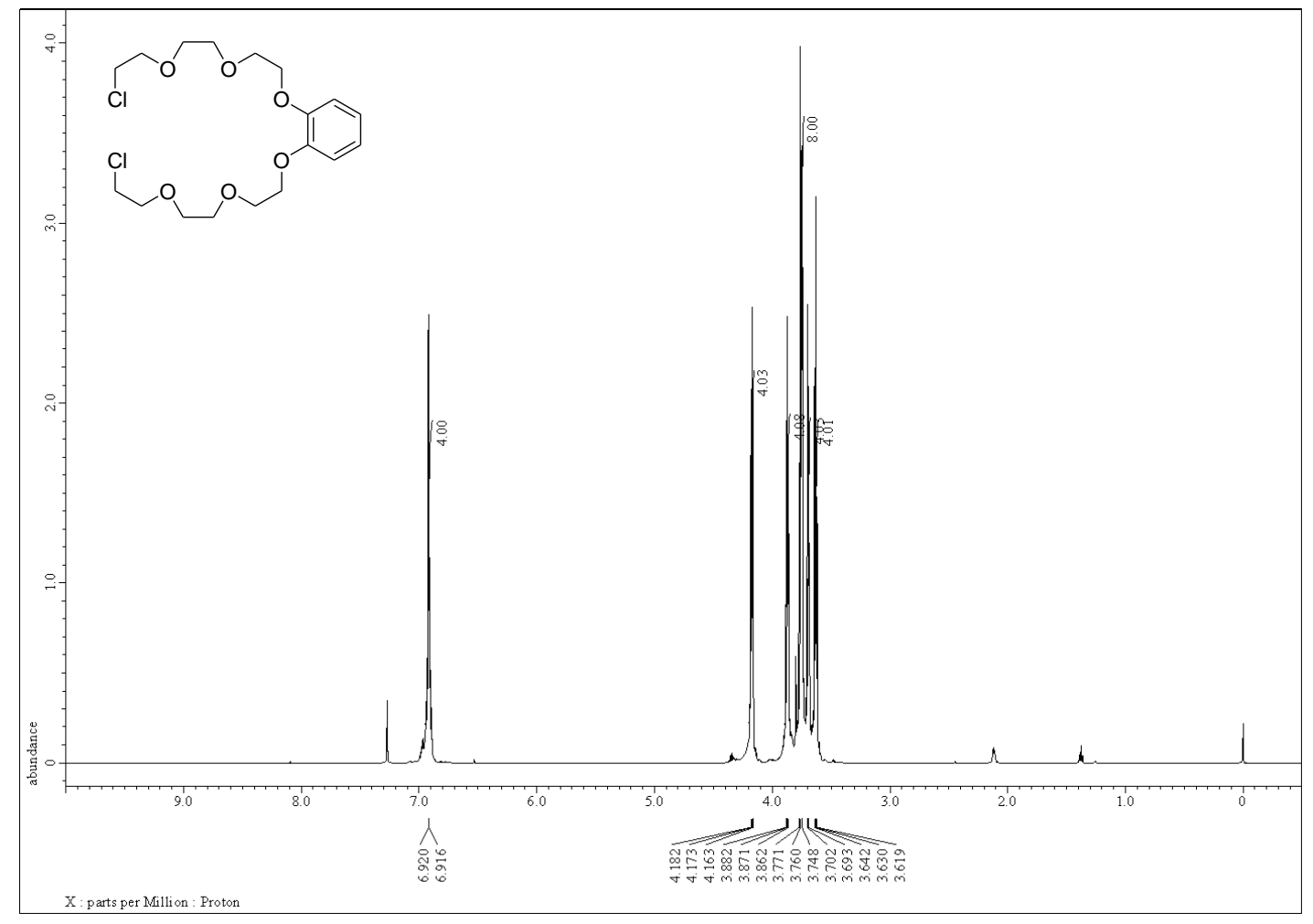

Figure S15a. ${ }^{1} \mathrm{H}$ NMR $\left(500 \mathrm{MHz}, \mathrm{CDCl}_{3}\right)$ spectrum of the dichloride 5.

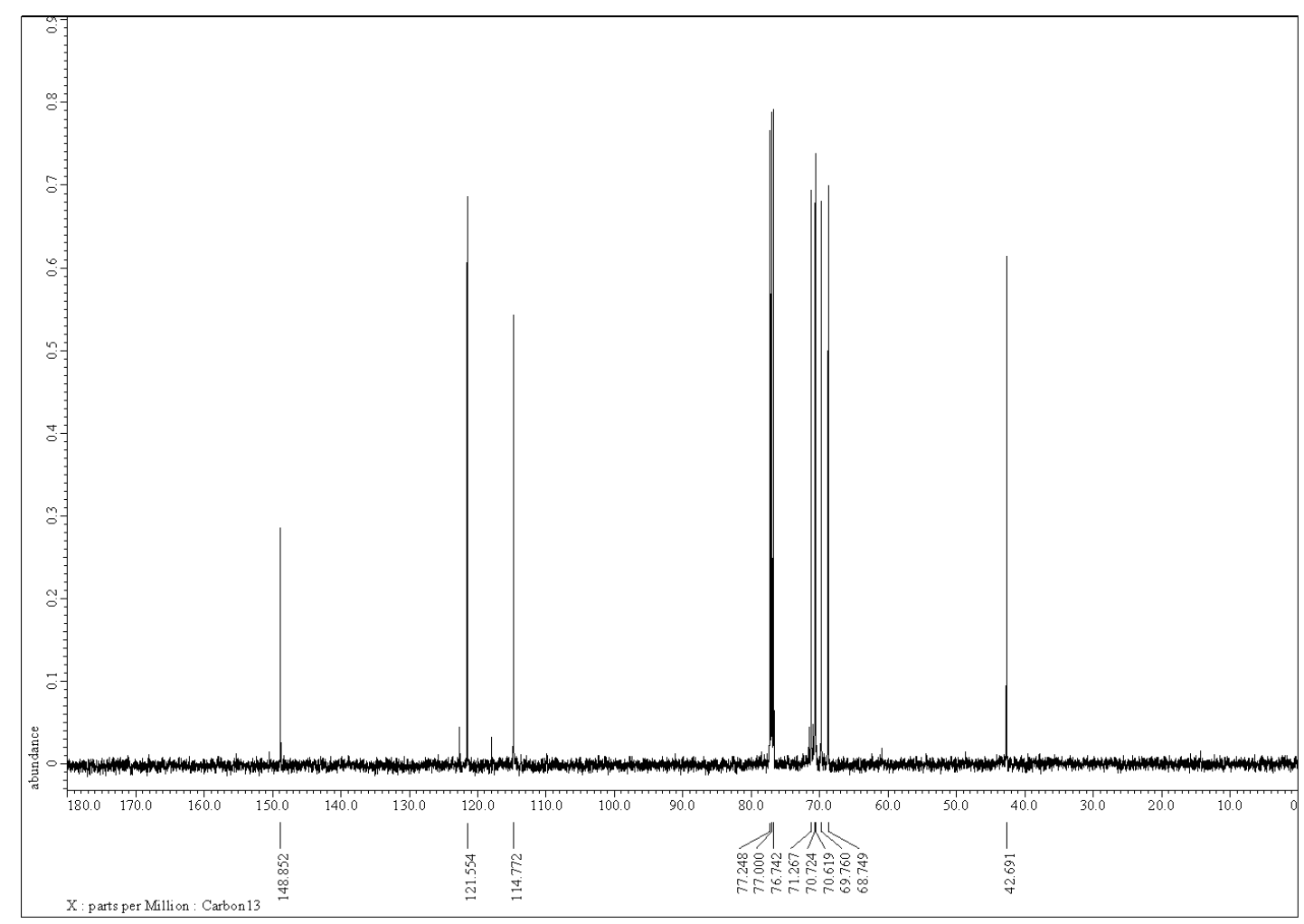

Figure S15b. ${ }^{13} \mathrm{C}$ NMR $\left(125 \mathrm{MHz}, \mathrm{CDCl}_{3}\right)$ spectrum of the dichloride 5 . 


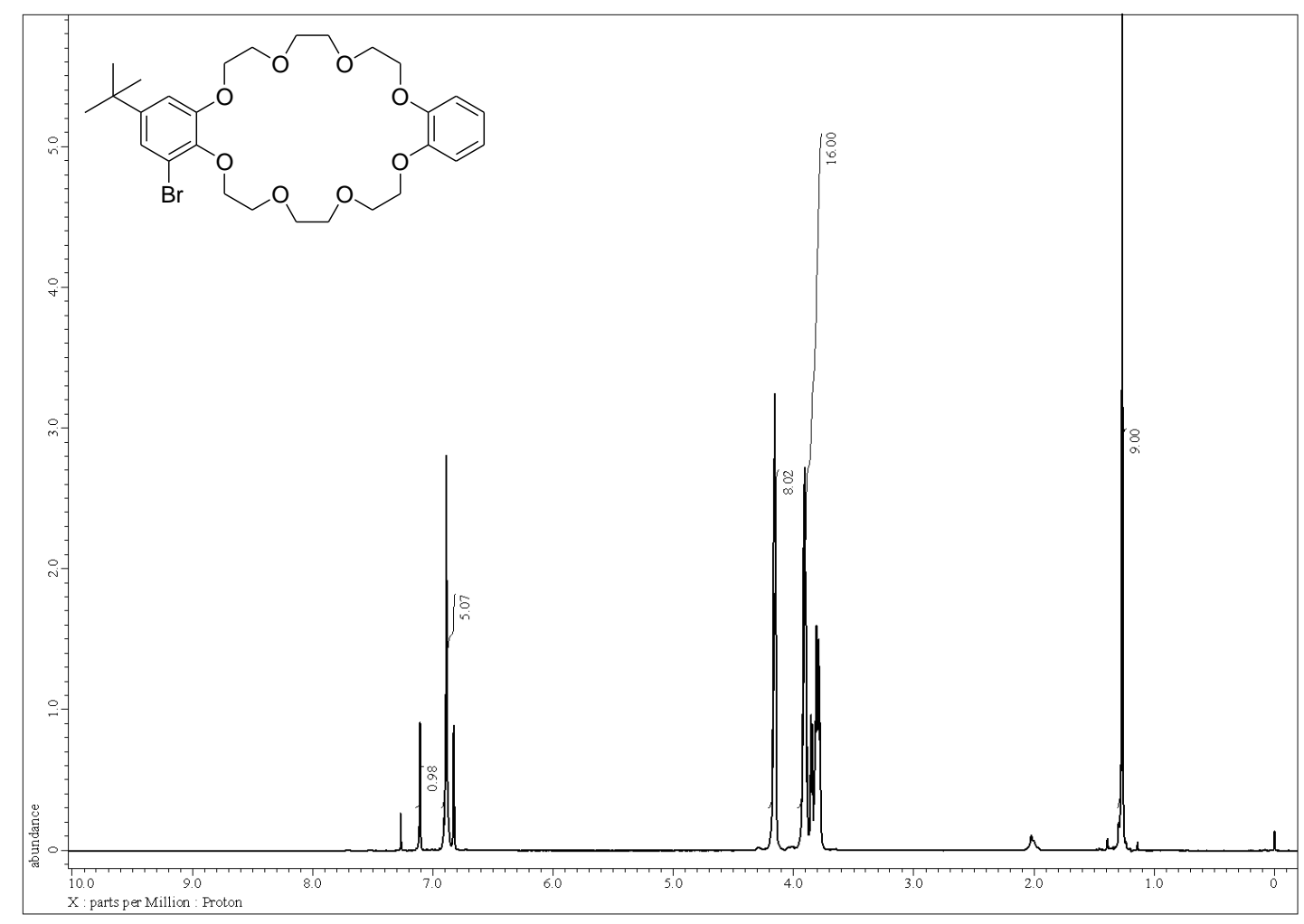

Figure S16a. ${ }^{1} \mathrm{H}$ NMR $\left(500 \mathrm{MHz}, \mathrm{CDCl}_{3}\right)$ spectrum of the mono-crown ether 6.

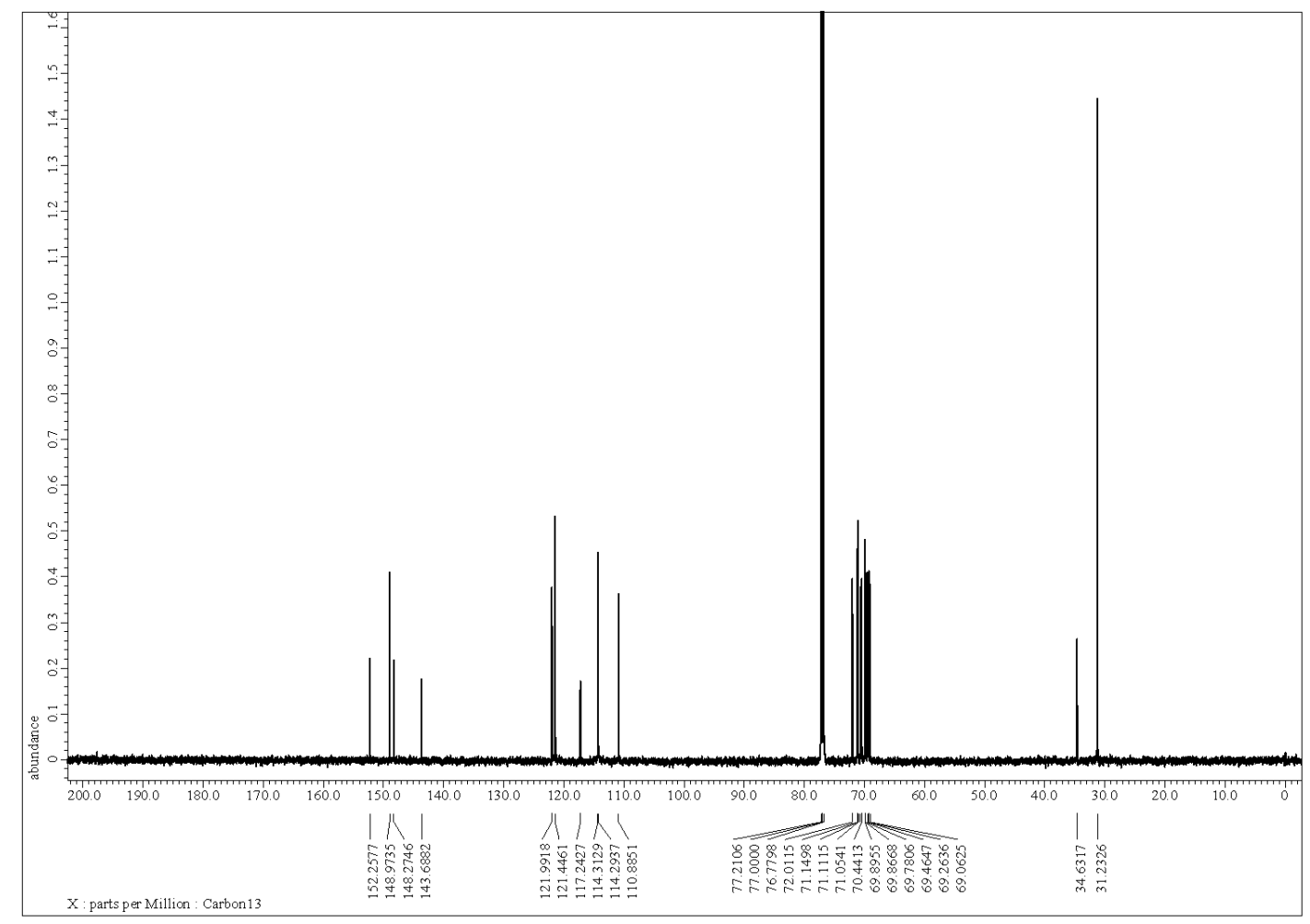

Figure S16b. ${ }^{13} \mathrm{C}$ NMR $\left(125 \mathrm{MHz}, \mathrm{CDCl}_{3}\right)$ spectrum of the mono-crown ether 6. 


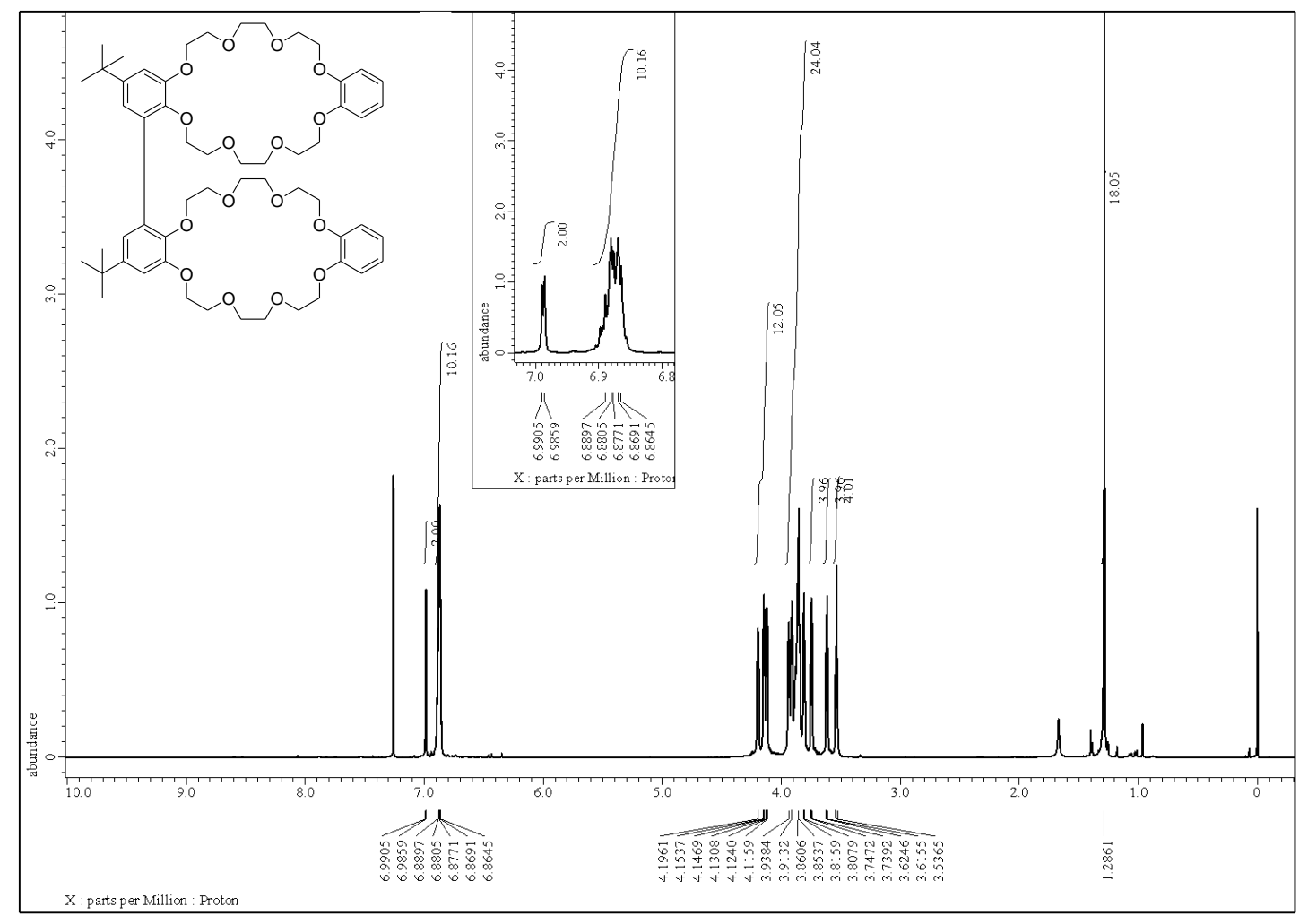

Figure S17a. ${ }^{1} \mathrm{H} \mathrm{NMR}\left(500 \mathrm{MHz}, \mathrm{CDCl}_{3}\right)$ spectrum of the bis-crown ether $\mathbf{1}$.

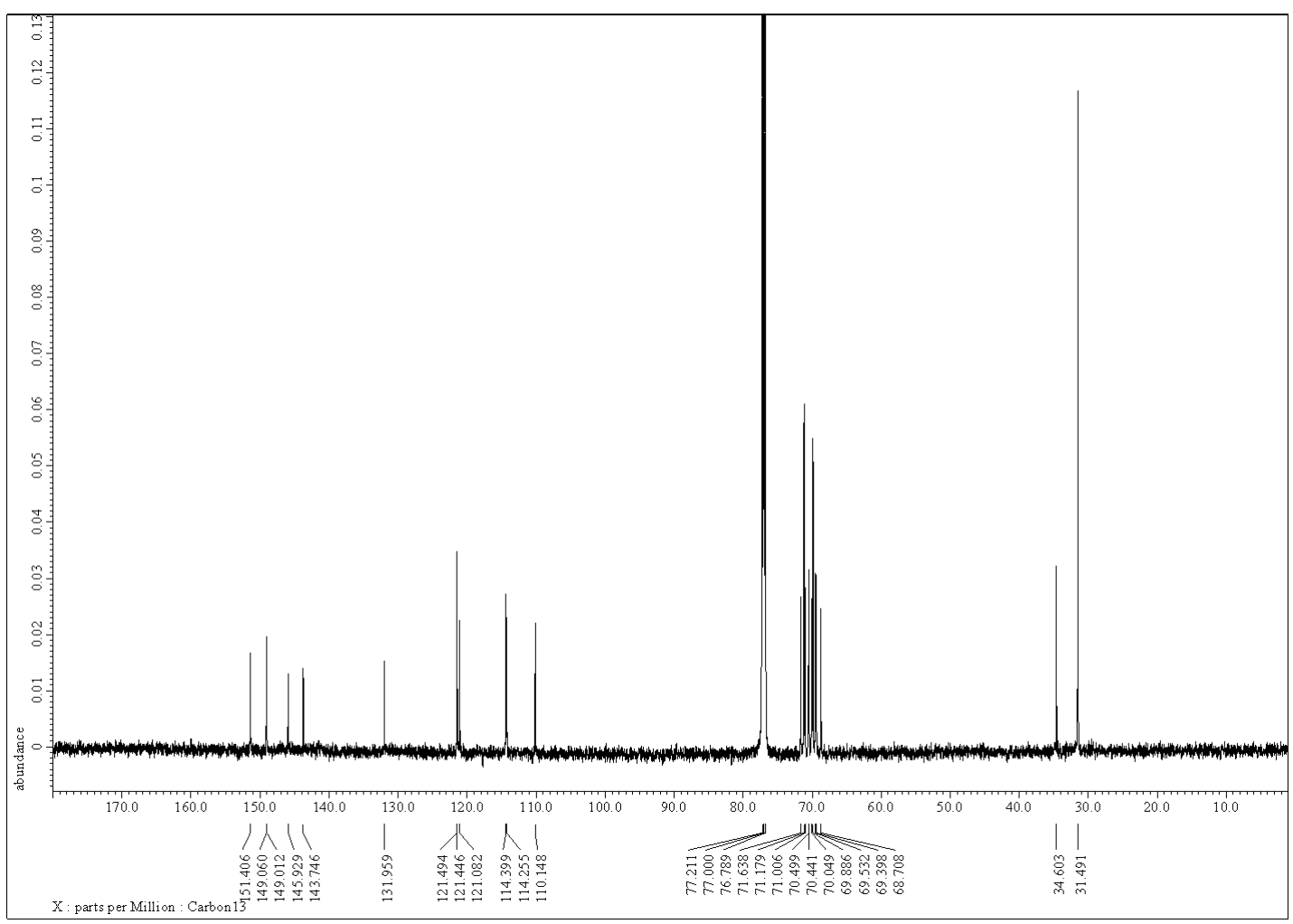

Figure S17b. ${ }^{13} \mathrm{C}$ NMR $\left(125 \mathrm{MHz}, \mathrm{CDCl}_{3}\right)$ spectrum of the bis-crown ether $\mathbf{1}$. 


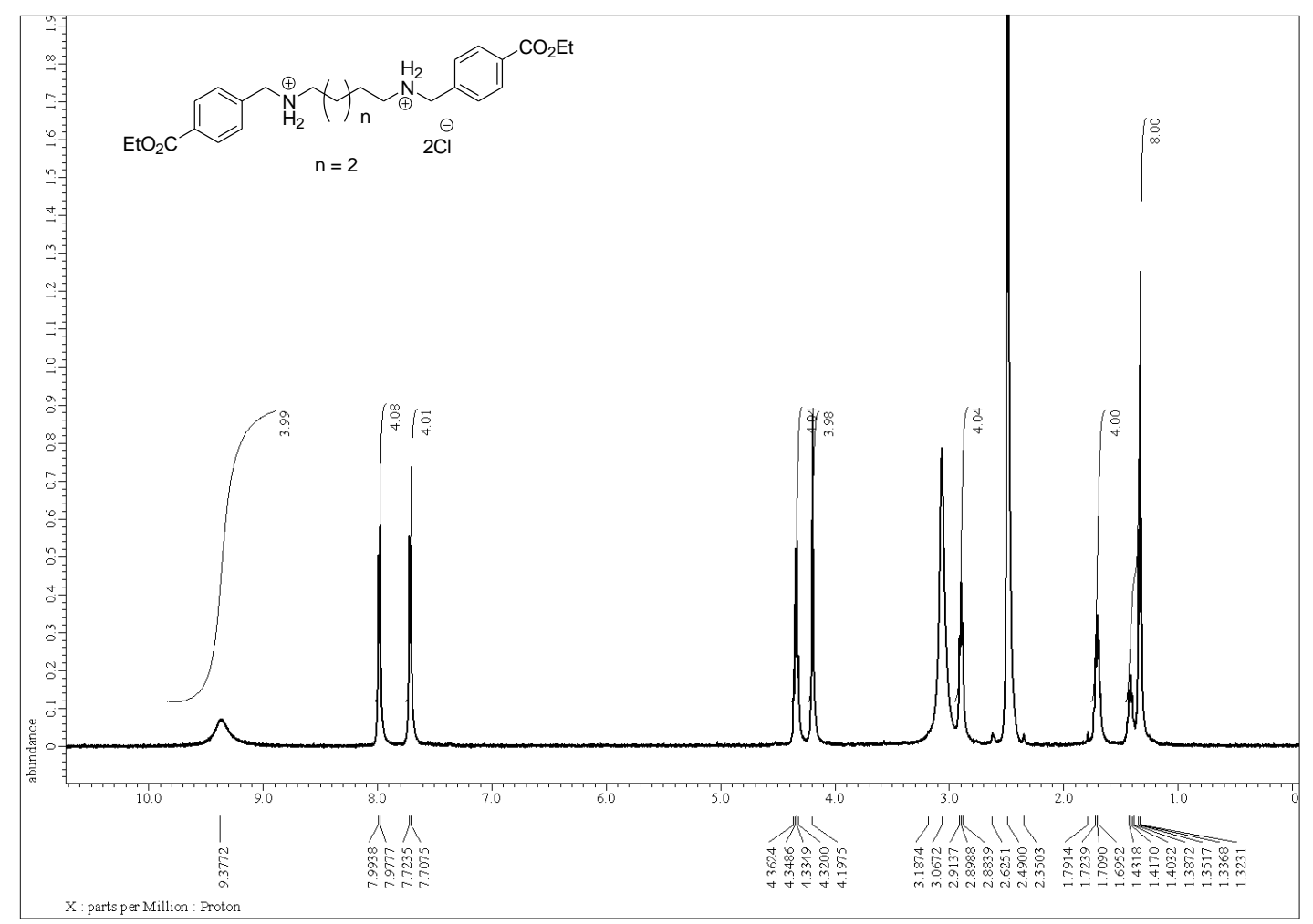

Figure S18a. ${ }^{1} \mathrm{H}$ NMR $\left(500 \mathrm{MHz}, \mathrm{DMSO}-d_{6}\right)$ spectrum of the bis-ammonium salt 7c.

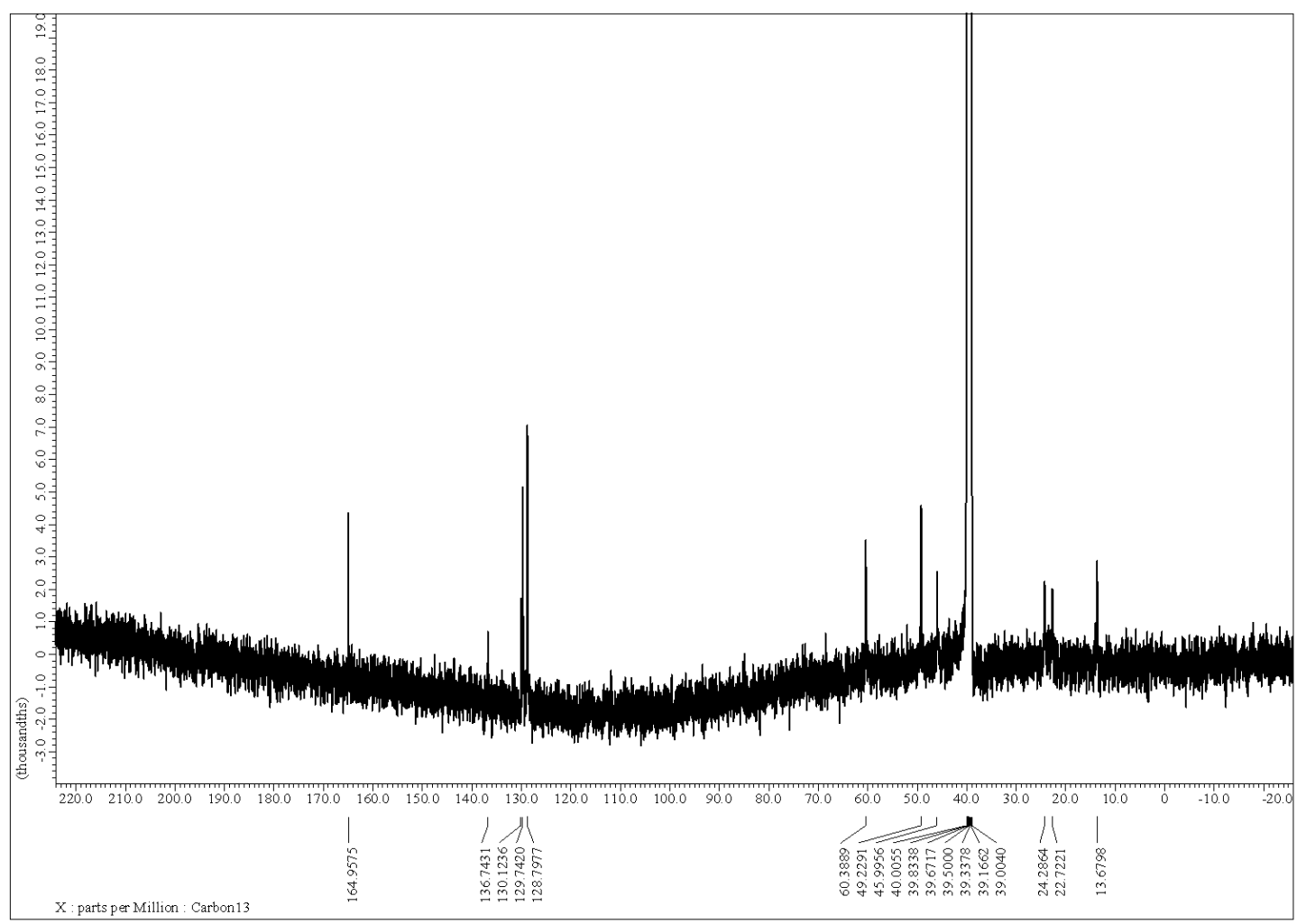

Figure S18b. ${ }^{13} \mathrm{C}$ NMR $\left(125 \mathrm{MHz}, \mathrm{DMSO}-d_{6}\right)$ spectrum of the bis-ammonium salt 7c. 


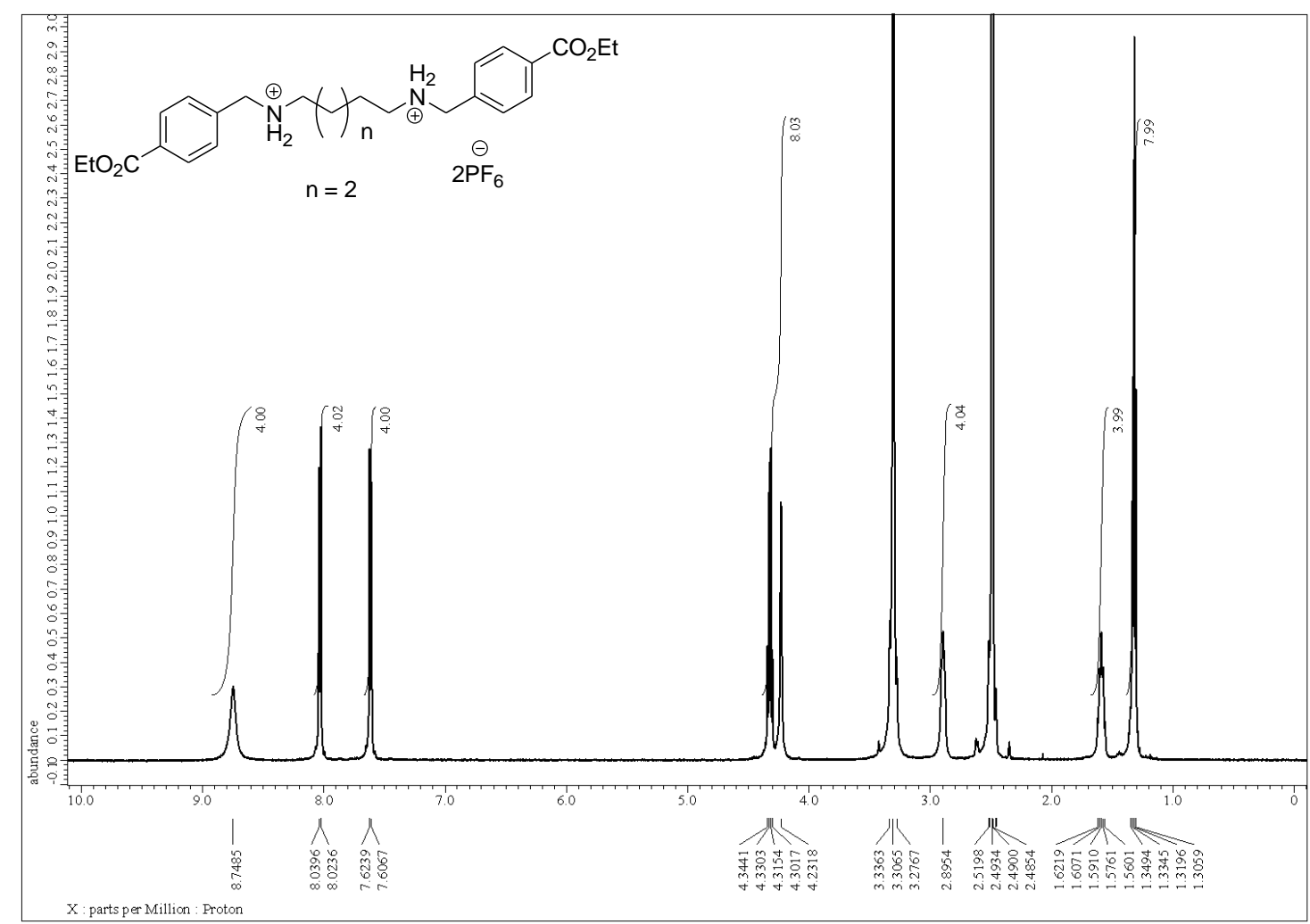

Figure S19a. ${ }^{1} \mathrm{H}$ NMR $\left(500 \mathrm{MHz}, \mathrm{DMSO}-d_{6}\right)$ spectrum of the bis-ammonium salt 7a.

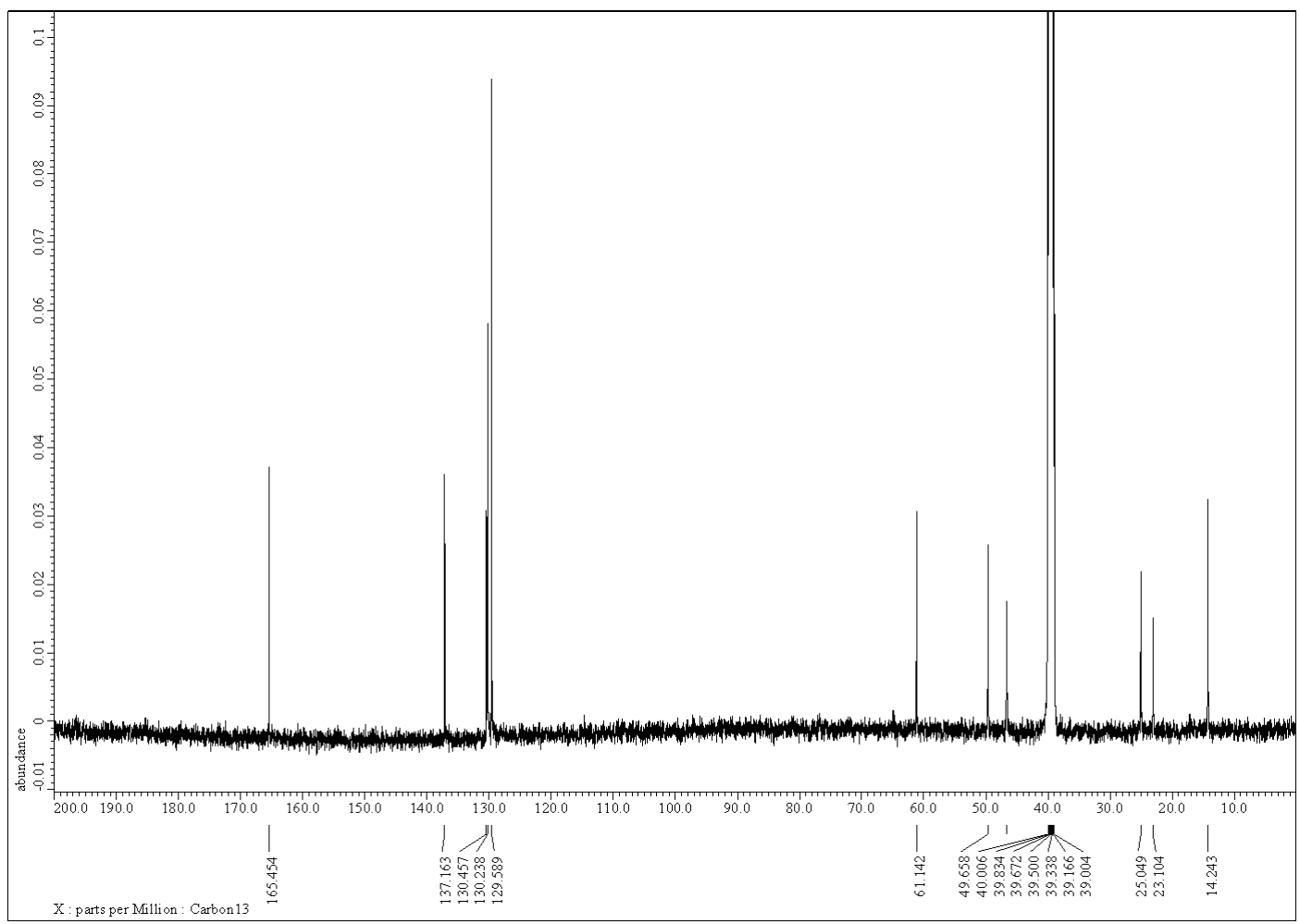

Figure S19b. ${ }^{13} \mathrm{C}$ NMR (125 MHz, DMSO- $\left.d_{6}\right)$ spectrum of the bis-ammonium salt 7a. 


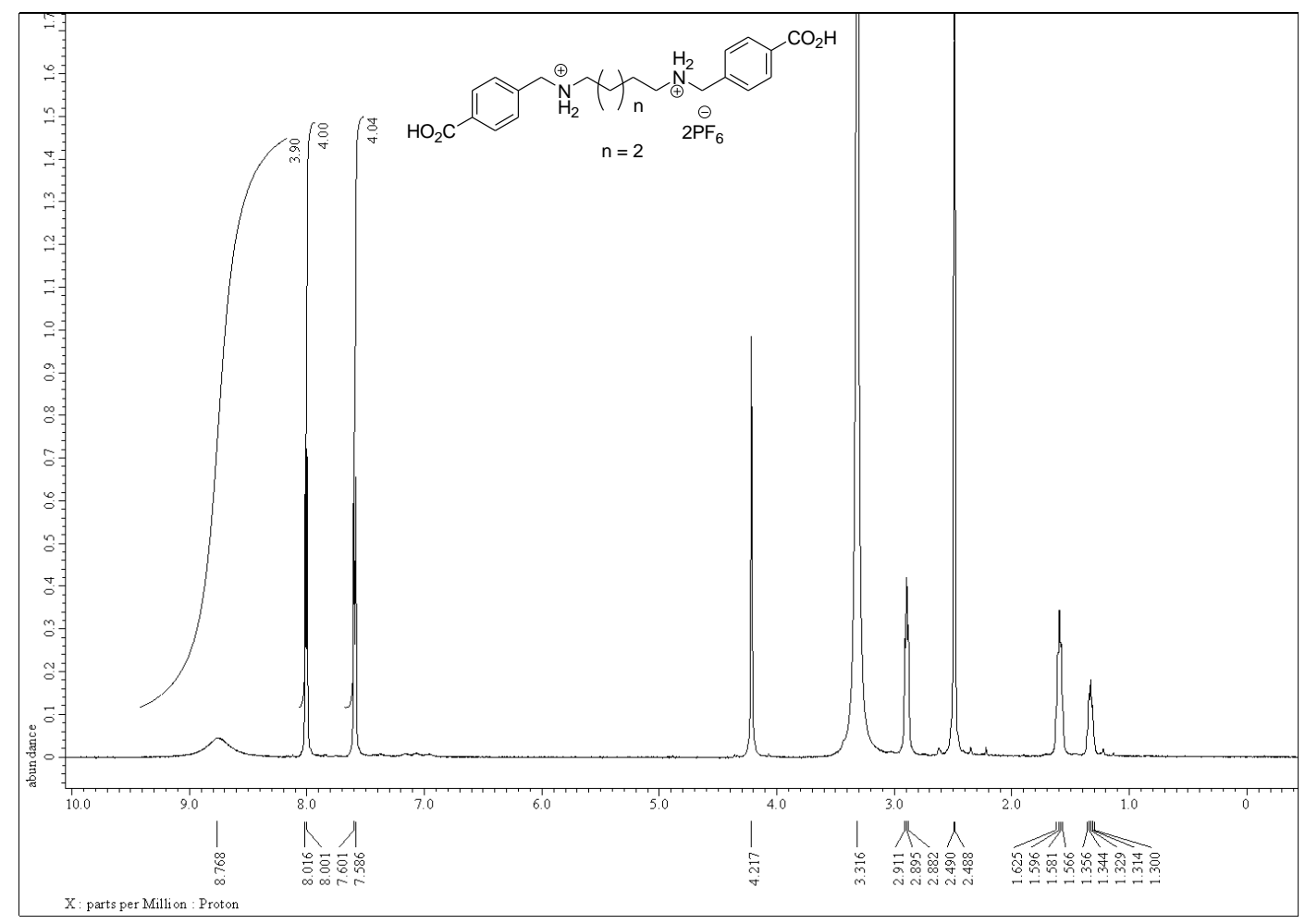

Figure S20a. ${ }^{1} \mathrm{H}$ NMR $\left(500 \mathrm{MHz}, \mathrm{DMSO}-d_{6}\right)$ spectrum of the bis-ammonium salt $\mathbf{7 b}$.

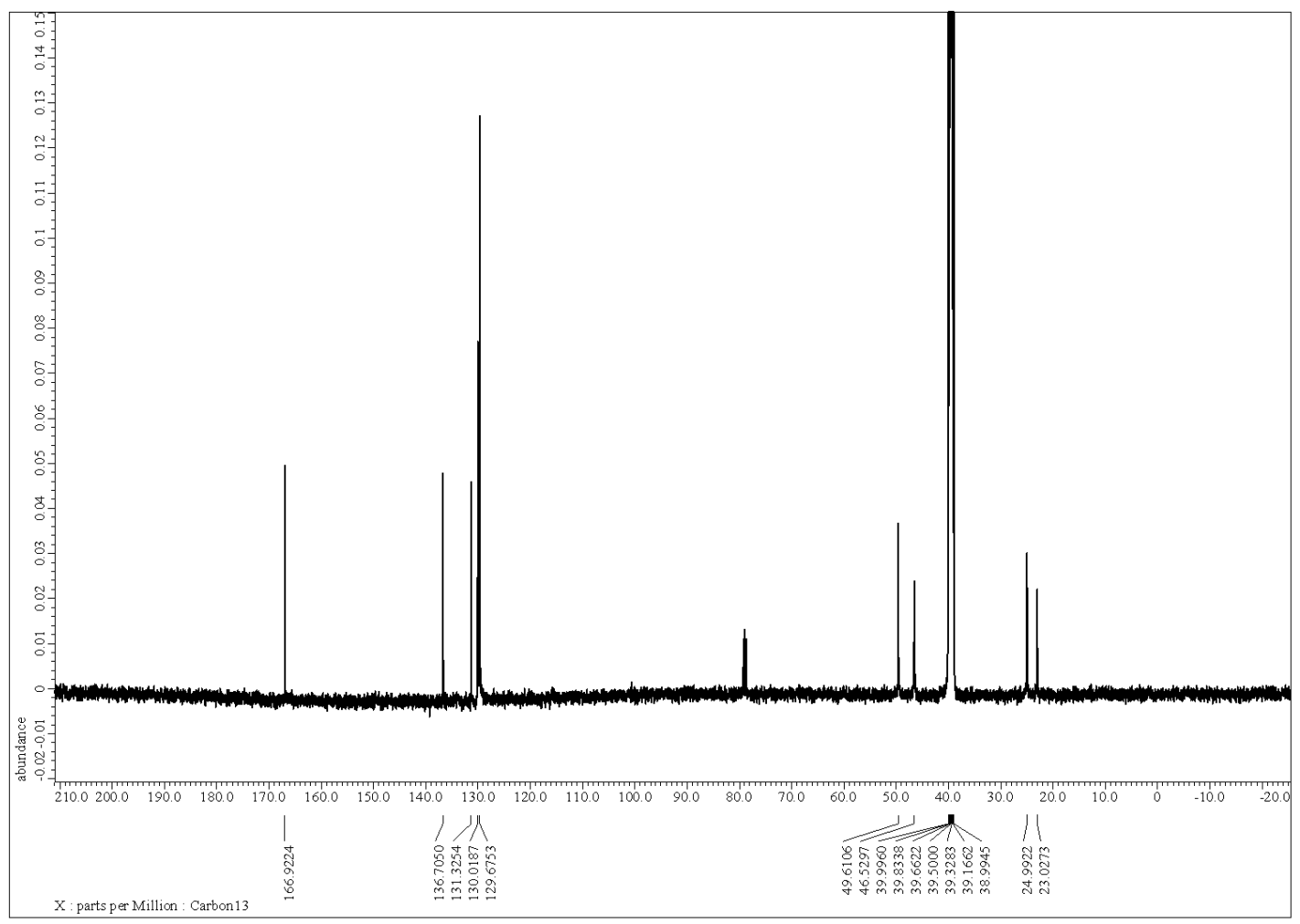

Figure S20b. ${ }^{13} \mathrm{C}$ NMR (125 MHz, DMSO- $\left.d_{6}\right)$ spectrum of the bis-ammonium salt $7 \mathbf{b}$. 

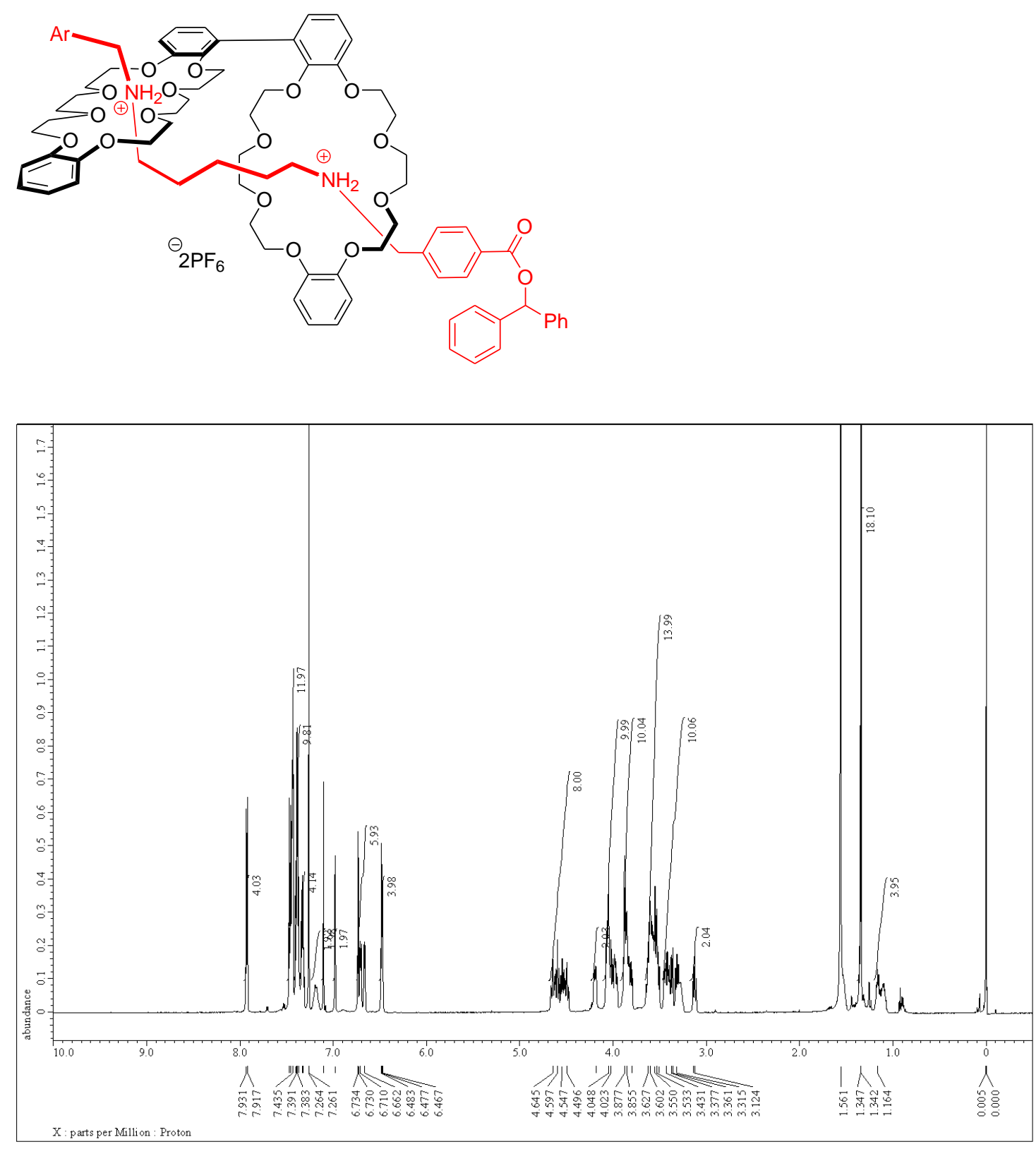

Figure S21a. ${ }^{1} \mathrm{H}$ NMR $\left(600 \mathrm{MHz}, \mathrm{CDCl}_{3}\right)$ spectrum of the [2]rotaxane 2. 


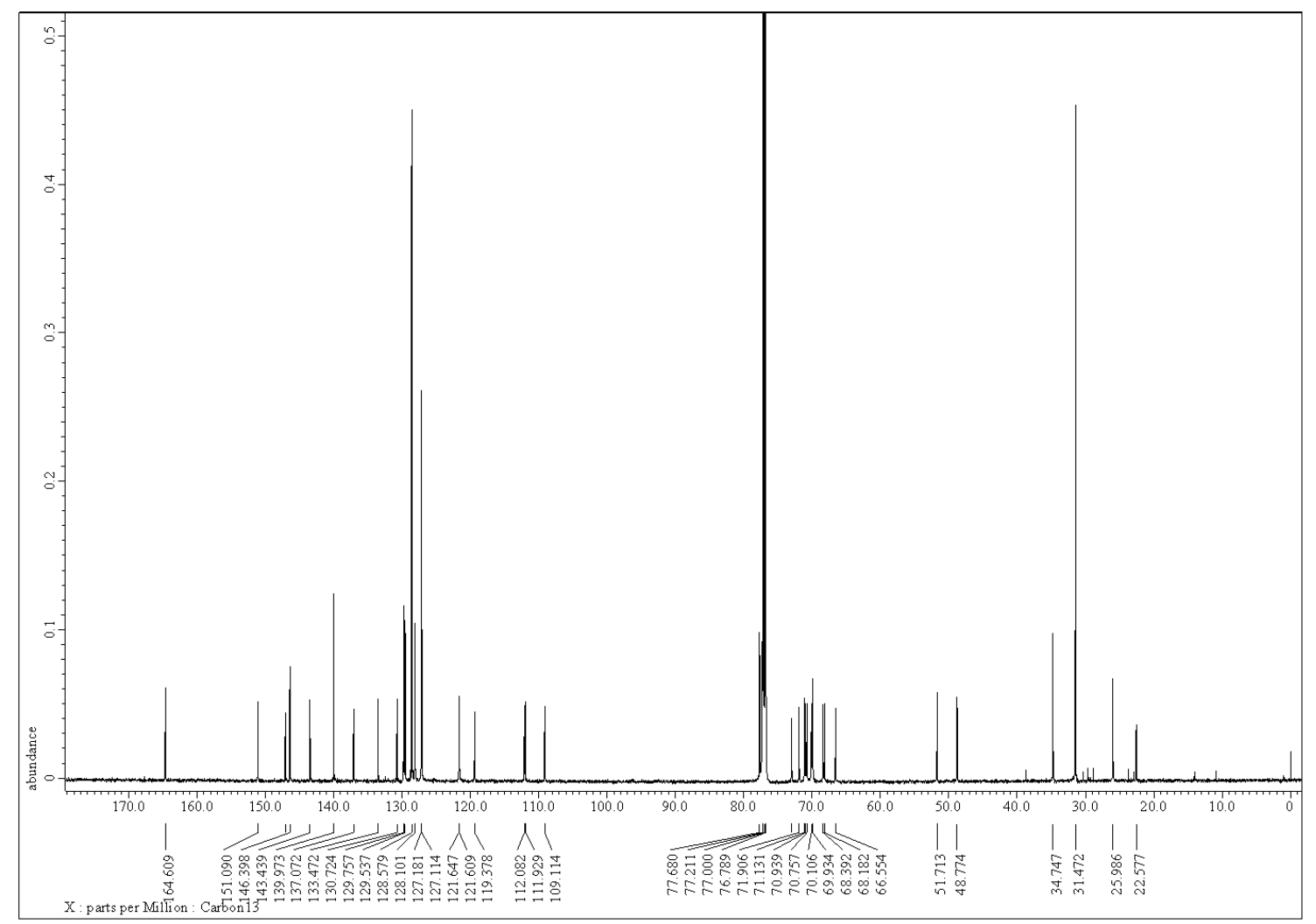

Figure S21b. ${ }^{13} \mathrm{C}$ NMR $\left(150 \mathrm{MHz}, \mathrm{CDCl}_{3}\right)$ spectrum of the [2]rotaxane 2. 